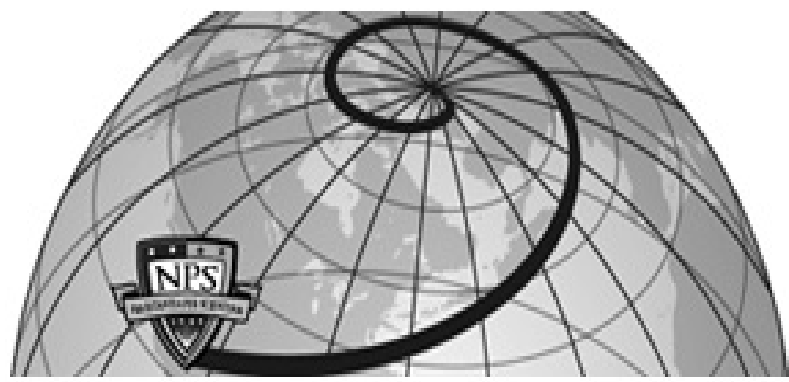

Calhoun: The NPS Institutional Archive DSpace Repository

\title{
A numerical study of the effects of wind forcing on the Chile Current System
}

$\mathrm{Hu}$, Chih-Ping

Monterey, California. Naval Postgraduate School

https://hdl.handle.net/10945/42822

This publication is a work of the U.S. Government as defined in Title 17, United States Code, Section 101. Copyright protection is not available for this work in the United States.

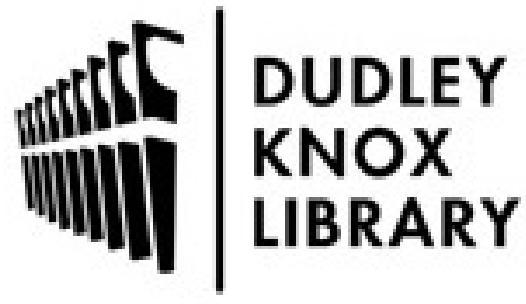

http://www.nps.edu/library
Calhoun is the Naval Postgraduate School's public access digital repository for research materials and institutional publications created by the NPS community. Calhoun is named for Professor of Mathematics Guy K. Calhoun, NPS's first appointed -- and published -- scholarly author.

Dudley Knox Library / Naval Postgraduate School 411 Dyer Road / 1 University Circle Monterey, California USA 93943 


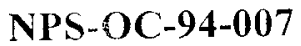 \\ NAVAL POSTGRADUATE SCHOOL Monterey, California}



THESIS

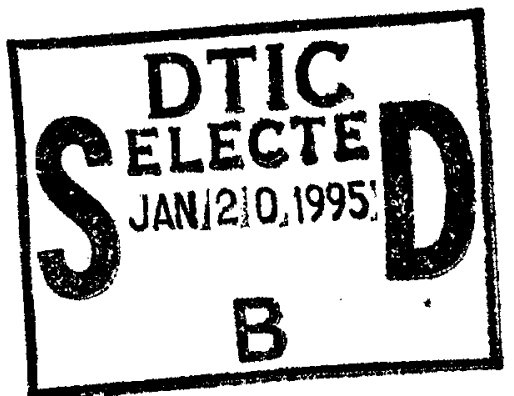

A NUMERICAL STUDY OF THE EFFECTS OF WIND
FORCING ON THE CHILE CURRENT SYSTEM

by

Chih-Ping $\mathrm{Hu}$

Decenber, 1994

Thesis Advisor:

Mary L. Batteen

Prepared for:

Approved for public release; distribution is unlimited.

Office of Naval Research

800 N. Quincy Strect

Arlington, VA 22217-5000

Hed 


\section{NAVAL POSTGRADUATE SCHOOL Monterey, California 93943}

Rear Admiral Thomas A. Mercer

Superintendent

This thesis was prepared in conjunction with research sponsored in part by the Office of Naval Research, 800 N. Quincy Street, Arlington, VA 22217-5000.

Reproduction of all or part of this report is authorized.

Released by:

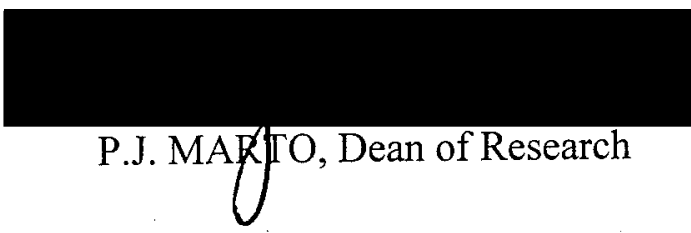




\begin{tabular}{|c|c|c|c|}
\hline RE & DOCUMENT & NPAGE & $\begin{array}{l}\text { Form Approved } \\
\text { OMB No. 0704-0188 }\end{array}$ \\
\hline \multicolumn{4}{|c|}{$\begin{array}{l}\text { Public reporting burden for theis collection of information is estimated to average } 1 \text { hour per response, including the time for reviewing instructions, searching existing data sources, gathering and } \\
\text { maintaining the data needed, and completing and reviewing the collection of information. Send comments regarding this burden estimate or any other aspect of this collection of information, } \\
\text { including suggetions for reducing this burden, to Washington Headquarters Services, Directorate for Intormation Operations and Reports, 1215 Jefferson Davis Highway. Suite 1204, Arlington, VA } \\
\text { 22202-4302. and to the Ottice of Management and Budget, Paperwork Reduction Project (0704-0188), Washington, DC 20503. }\end{array}$} \\
\hline $\begin{array}{l}\text { 1. AGENCY USE ONLY (Leave } \\
\text { Blank) }\end{array}$ & $\begin{array}{l}\text { 2. REPORT DATE } \\
\text { December, } 1994\end{array}$ & \multicolumn{2}{|c|}{ Master's Thesis } \\
\hline \multicolumn{3}{|c|}{$\begin{array}{l}\text { 4. TITLE AND SUBTITLE } \\
\text { A NUMERICAL STUDY OF THE EFFECTS OF WIND FORCING ON THE CHILE } \\
\text { CURRENT SYSTEM }\end{array}$} & \multirow[t]{2}{*}{ 5. FUNDING NUMBERS } \\
\hline \multicolumn{3}{|c|}{$\begin{array}{l}\text { 6. AUTHOR(S) } \\
\text { Hu, Chih-Ping, in conjunction with Mary Batteen }\end{array}$} & \\
\hline \multicolumn{3}{|c|}{ 7. PERFORMING ORGANIZATION NAMES(S) AND ADDRESS(ES) } & $\begin{array}{l}\text { 8. PERFORMING ORGANIZATION } \\
\text { REPORT NUMBER } \\
\text { NPS-OC-94-007 }\end{array}$ \\
\hline $\begin{array}{r}\text { 9. SPONSORING/MONITORING } \\
\text { Offi } \\
800 \\
\text { Arlir }\end{array}$ & $\begin{array}{l}\text { AME(S) AND ADDRESS(ES) } \\
\text { val Research } \\
\text { cy Street } \\
\text { A } 22217-5000\end{array}$ & & $\begin{array}{l}\text { 10. SPONSORING/MONITORING } \\
\text { AGENCY REPORT NUMBER }\end{array}$ \\
\hline
\end{tabular}

11. SUPPLEMENTARY NOTES

The views expressed in this thesis are those of the author and do not reflect the official policy or position of the Department of Defense or the US Government.

12a. DISTRIBUTION/AVAILABILITY STATEMENT

12b. DISTRIBUTION CODE

Approved for public release; distribution is unlimited.

13. ABSTRACT (Maximum 200 words)

A high-resolution, multi-level, primitive equation ocean model is used to examine the response of the coastal region from $22.5^{\circ} \mathrm{S}$ to $35^{\circ} \mathrm{S}$ of the Chile Current System to both equatorward and climatological wind forcing. The results from both types of forcing show that an equatorward surface current, a poleward undercurrent, upwelling, meanders, filaments and eddies develop in response to the predominant equatorward wind forcing. When climatological wind forcing is used, an offshore branch of the equatorward surface current is also generated. These features are consistent with available observations of the Chile Current System. The model results support the hypothesis that wind forcing is an important mechanism for generating currents, eddies and filaments in the Chile eastern boundary current system and in other eastern boundary current regions which have predominantly equatorward wind forcing.

14. SUBJEct TERMS
Primitive equation model, Chile Current System, eddies, filaments, jets, undercurrent, wind forcing, currents. 16. PRICE CODE 
Approved for public release; distribution is unlimited.

\section{A NUMERICAL STUDY OF THE EFFECTS OF WIND FORCING ON THE CHILE CURRENT SYSTEM}

by

\section{Chih-Ping $\mathrm{Hu}$}

Lieutenant Commander, Taiwan Navy

B.S.. Chung-Chang Institute of Technology, 1984

Submitted in partial fulfillment of the

requirements for the degree of

\section{MASTER OF SCIENCE IN PHYSICAL OCEANOGRAPHY}

from the

\section{NAVAL POSTGRADUATE SCHOOL \\ December, 1994}



Mary L. Batteen, Thesis Advisor

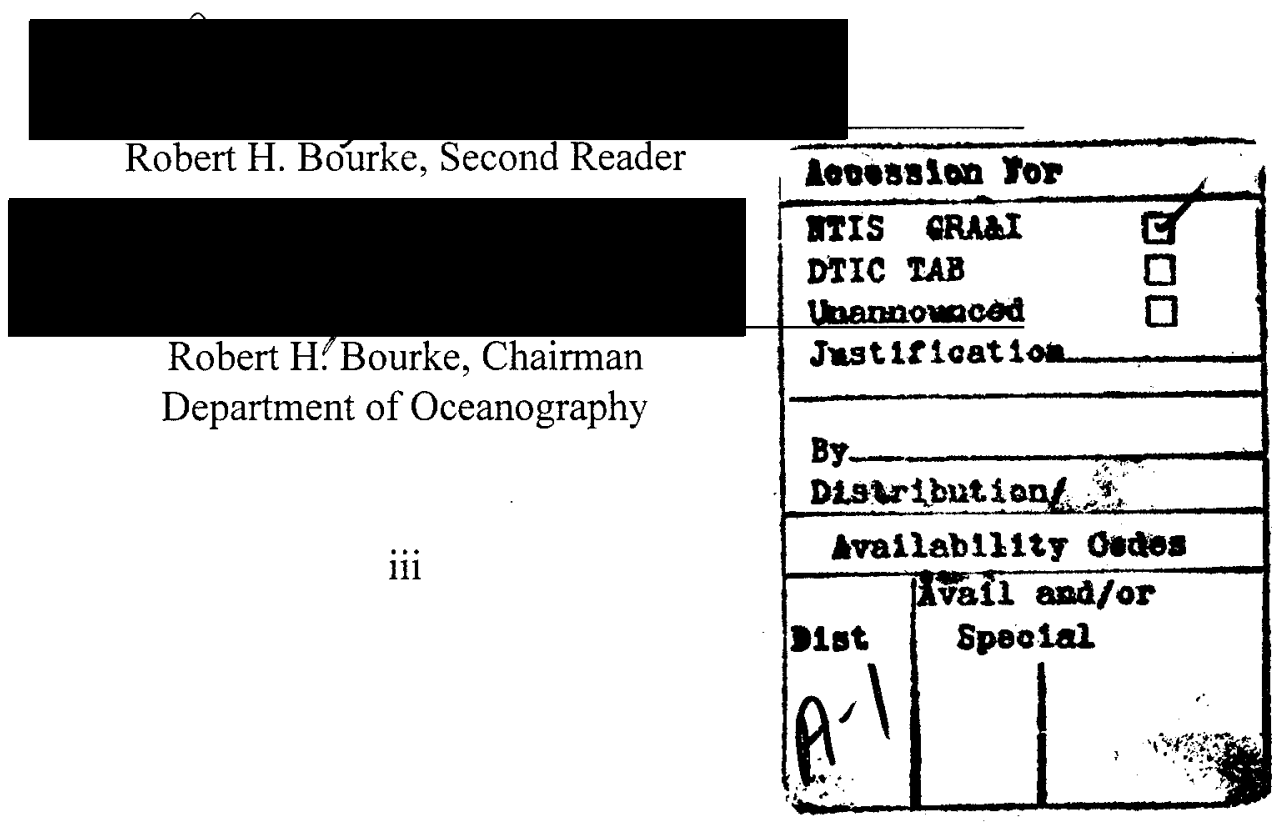



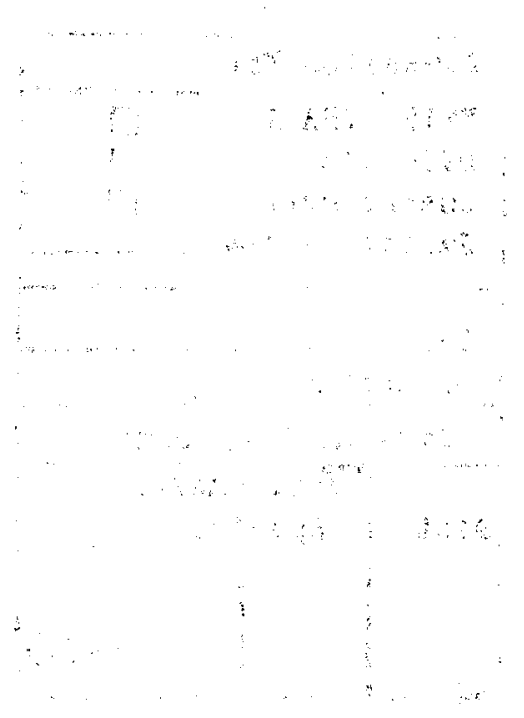


\begin{abstract}
A high-resolution, multi-level, primitive equation ocean model is used to examine the response of the coastal region from $22.5^{\circ} \mathrm{S}$ to $35^{\circ} \mathrm{S}$ of the Chile Current System to both equatorward and climatological wind forcing. The results from both types of forcing show that an equatorward surface current, a poleward undercurrent, upwelling, meanders, filaments and eddies develop in response to the predominant equatorward wind forcing. When climatological wind forcing is used, an offshore branch of the equatorward surface current is also generated. These features are consistent with available observations of the Chile Current System. The model results support the hypothesis that wind forcing is an important mechanism for generating currents, eddies and filaments in the Chile eastern boundary current system and in other eastern boundary current regions which have predominantly equatorward wind forcing.
\end{abstract}




\section{TABLE OF CONTENTS}



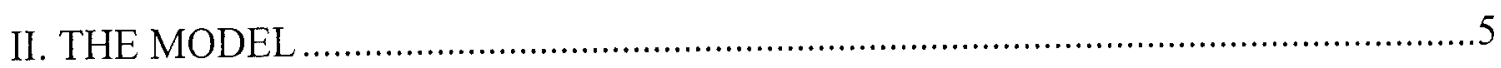

A. MODEL DESCRIPTION AND INITIAL CONDITIONS .............................5

B. SPECIFIC EXPERIMENTAL DESIGN ................................................

1. Experiment 1: Constant Equatorward Winds...................................

2. Experiment 2: Variable Climatological Winds................................. 7

C. ENERGY ANALYSIS TECHNIQUE ................................................ 8

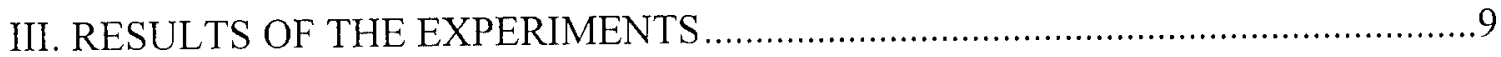

A. EXPERIMENT 1 -- CONSTANT EQUATORWARD WINDS .....................9

B. EXPERIMENT 2 -- VARIABLE CLIMATOLOGICAL WINDS ..................10

C. COMPARISON OF MODEL RESULTS WITH OBSERVATIONS..............12

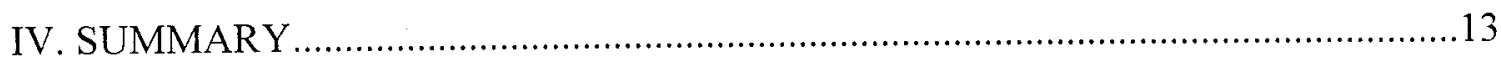

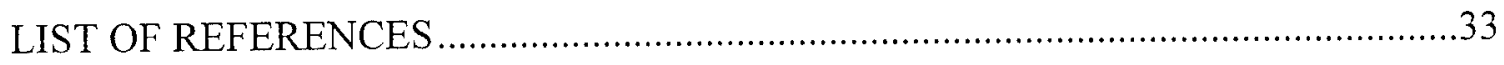

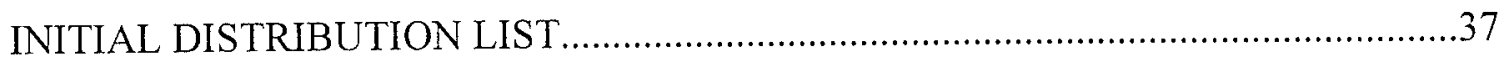


viii 


\section{LIST OF FIGURES}

1. Wind stress fields for the time period (a) April-May, (b) June-July, (c) AugustSeptember, (d) October-November, (e) December-January, and (f) February-March. Vectors are scaled in units of $d y n e / \mathrm{cm}^{2}$. Ellipses show areas of large standard errors (after Bakun and Nelson, 1991).

2. Generalized circulation schematic for the Chile Current System (after Codispoti et al. 1989): The broad equatorward Chile-Peru Current (CPC) (solid lines) separates into two branches: the coastal CPC and the oceanic $\mathrm{CPC}$. The coastal CPC overlies the poleward undercurrent, known as the Peru-Chile Undercurrent (dashed line).

3. Model Domain: Area of study is a $1152 \mathrm{~km}$ (cross-shore) by $1280 \mathrm{~km}$ (alongshore) box off the coast of Chile.

4. Temperature profile (i.e., temperature in degrees Celsius versus depth in meters) used in the model: A smooth exponential curve (solid line) was used to approximate the climatological temperature profile (solid line with small circles) computed from Levitus (1982).

5. Climatological (1980 - 1989) ECMWF winds in $\mathrm{m} / \mathrm{s}$ : (a) day 90 , (b) day 180 , (c) day 270 , (d) day 360. The latitudinal grid point 1 (129) corresponds to $35^{\circ} \mathrm{S}\left(22.5^{\circ} \mathrm{S}\right)$. The longitudinal grid point $1(129)$ corresponds to $82.5^{\circ} \mathrm{W}\left(72.5^{\circ} \mathrm{W}\right)$. Maximum wind vector is $20 \mathrm{~m} / \mathrm{s}$.

6. Experiment 1: Surface velocity vectors in the coastal region at days (a) 30, (b) 45 , (c) 105, and (d) 360 . To avoid clutter, velocity vectors are plotted at every third grid point in both the cross-shore and alongshore directions, and velocities less than 5 $\mathrm{cm} / \mathrm{s}$ are not plotted. The numbers associated with the highs in Figures $6 \mathrm{c}$ and $6 \mathrm{~d}$ correspond to temperature, not velocity. Maximum current vector is $80 \mathrm{~cm} / \mathrm{s}$.

7. Experiment 1: Cross-shore section at $\mathrm{y} \sim 640 \mathrm{~km}\left(\sim 29^{\circ} \mathrm{S}\right)$ of the meridional component of velocity at day 30 . Solid lines indicate equatorward flow, while dashed lines 
indicate poleward flow. The contour interval is $2 \mathrm{~cm} / \mathrm{s}$. The maximum equatorward velocity is $\sim 20 \mathrm{~cm} / \mathrm{s}$ at the surface, $\sim 50 \mathrm{~km}$ off the coast.

8. Experiment 1: Surface temperature in the coastal region at days (a) 30 , (b) 45 , (c) 75 , (d) 105 , and (e) 360 . The contour interval is $0.5^{\circ} \mathrm{C}$. The temperature decreases toward the coast. Note the existence of upwelling and meanders....... .22

9. Experiment 1: Energy transfers in the coastal region of (a) mean to eddy kinetic energy (i.e., barotropic energy transfer) and (b) eddy potential to eddy kinetic energy (i.e., baroclinic energy transfer) for model days 39 to 60 . The contour interval is 10

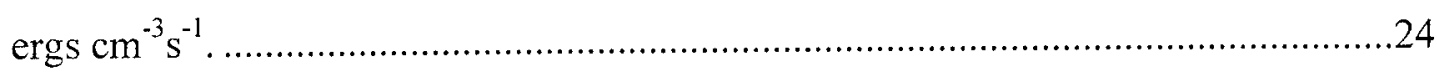

10. Experiment 2: Surface velocity vectors in the coastal region at days (a) 30 , (b) 45 , (c) 135 , (d) 180 , (e) 225, and (f) 360 . To avoid clutter, velocity vectors are plotted at every third grid point in both the cross-shore and alongshore directions, and velocities less than $5 \mathrm{~cm} / \mathrm{s}$ are not plotted. The numbers associated with the highs in Figures $10 \mathrm{~d}$ and $10 \mathrm{f}$ correspond to temperature, not velocity. Maximum current vector is $80 \mathrm{~cm} / \mathrm{s}$.

11. Experiment 2: Cross-shore section at $y \sim 640 \mathrm{~km}\left(\sim 29^{\circ} \mathrm{S}\right)$ of the meridional component of velocity at day 30 . Solid lines indicate equatorward flow, while dashed lines indicate poleward flow. The contour interval is $2 \mathrm{~cm} / \mathrm{s}$. The maximum equatorward velocity is $\sim 20 \mathrm{~cm} / \mathrm{s}$ at the surface, $\sim 50 \mathrm{~km}$ off the coast.

12. Experiment 2: Surface temperature at days (a) 45, (b) 135, (c) 180, (d) 225, and (e) 360. The contour interval is $0.5^{\circ} \mathrm{C}$. The temperature decreases toward the coast. Note the existence of upwelling and meanders. .28

13. Experiment 2: Energy transfers in the coastal region of (a) mean to eddy kinetic energy (i.e., barotropic energy transfer) and (b) eddy potential to eddy kinetic energy (i.e., baroclinic energy transfer) for model days 120 to 135 . The contour interval is 10 ergs $\mathrm{cm}^{-3} \mathrm{~s}^{-1}$. .30 


\section{ACKNOWLEDGMENT}

The author wants to thank Dr. Mary Batteen as the thesis advisor for her guidance and patience during the work in performing this investigation. Additional thanks to LCDR Christopher Butler for his endless assistance with Wordperfect, and to Mike Cook for obtaining the European Center for Medium-Range Weather Forecasts wind data. 


\section{INTRODUCTION}

The eastern boundary current (EBC) system off the west coast of Chile is part of the Peru Humboldt coastal upwelling system, which extends from $5^{\circ} \mathrm{S}$ to $50^{\circ} \mathrm{S}$. This system is influenced predominantly by equatorward winds throughout the year (Figure 1). The direction, and to a large degree the magnitude of the winds, are the result of a semipermanent subtropical high pressure system that is similar in nature and behavior to its counterpart in the Northern Hemisphere, the North Pacific Subtropical High, as described in Nelson (1977). The South Pacific Subtropical High migrates meridionally with the seasons, reaching its northernmost extent during the austral winter (Figures 1b, 1c), with its center located roughly at $25^{\circ} \mathrm{S}$. As the seasons progress, the high pressure system moves southward until its center reaches about $32.5^{\circ} \mathrm{S}$ during the austral summer (Figures 1e, 1f).

Because of this migration, maximum values of wind stress (Figure 1) vary temporally at given locations. North of Chile, for example, the maximum wind stress is seen during the austral winter (Figures 1b, 1c), presumably because the South Pacific Subtropical High reaches its northernmost migration at that time, and the resulting winds take on more of an alongshore characteristic. The middle of the Chilean coastline, in contrast, does not experience maximum wind stress values until late spring and summer (Figures 1d, 1e).

The oceanic regime adjacent to the coast of Chile is comprised of several major features (see Figure 2), including an equatorward surface current called the Chile-Peru Current ( $\mathrm{CPC}$ ) and a poleward undercurrent known as both the Gunther Current and the Peru-Chile Undercurrent (PCU). The climatological CPC is similar to other EBCs in that it is a sluggish $(\operatorname{Order}(10 \mathrm{~cm} / \mathrm{s}))$, wide and generally shallow flow moving equatorward along a west coast (Wooster and Reid, 1963). Mass transports have been estimated to be $\sim 19 \times 10^{6} \mathrm{~m}^{3} / \mathrm{s}$ (Wooster and Reid, 1963). The primary source of the CPC is, as expected, the West Wind Drift, because the South American continent extends far enough south to intercept at least part of the flow, and divert it towards the north. The CPC consists of two equatorward currents (Tchernia, 1980; Gunther, 1936). The outer current 
is usually referred to as the oceanic $\mathrm{CPC}$, which has a maximum depth of $\sim 700 \mathrm{~m}$ (Tchernia 1980). The inner surface current is known as the coastal CPC, which extends to $\sim 200 \mathrm{~m}$ depth (Tchernia, 1980).

Until recently, the PCU had been relatively unexplored. Although Gunther (1936) discussed the undercurrent that would eventually carry his name, very little additional research was conducted on the PCU until 1961, when Wooster and Gilmartin (1961) measured it using parachute drogues. Their article sparked a new interest in the region. and soon several expeditions set out to study the waters adjacent to the South American coast. Between 1960 and 1982 the area was explored by twelve different expeditions (Fonseca, 1989). Results of the expeditions revealed that the PCU is present all year, has its core at $\sim 150-200 \mathrm{~m}$ depth, is principally located between the coast and $200 \mathrm{~km}$ offshore, has average speeds on the order of $10 \mathrm{~cm} / \mathrm{s}$, and has a mass transport of $\sim 10 \mathrm{x}$ $10^{6} \mathrm{~m}^{3} / \mathrm{s}$ (Fonseca, 1989).

Recent observations have shown that, superimposed on the broad, climatological mean flow in this and other EBC regions, such as the California Current System, are highly energetic, mesoscale features such as meanders, eddies and filaments (Mooers and Robinson, 1984). These features have been observed during periods of predominantly equatorward winds, which are favorable for upwelling. These observations provide evidence for wind forcing as a possible important mechanism for the formation of currents, meanders, eddies, and filaments in EBC regions.

The Chile Current System offers a unique opportunity to isolate the effects of predominantly equatorward winds in an EBC system. Since the coastline is relatively straight (see Figure 3), there should be no significant effects of wind forcing with irregular coastline geometry (such as capes and bays). Also, since the topography abruptly drops off the coast to the Peru-Chile Trench, there should be no major effects of wind forcing with topography.

In contrast, the other $\mathrm{EBC}$ regions that have predominantly equatorward winds, such as the central and southern regions of the California Current System, have irregular coastline geometry and topography. Also, in other EBC regions where the coastlines are 
relatively straight, such as in the northern regions of the California Current System and of the Canary Current System, the wind stress is predominantly equatorward only during the upwelling season, from around April to September (During the rest of the year, the winds reverse and become predominantly poleward.). In the EBC region off Western Australia, the winds are predominantly equatorward and the coastline is relatively straight; however, the thermal forcing is so strong in this region that the predominantly observed surface current (the Leeuwin Current) opposes the winds (e.g., Batteen et al. 1992b).

There have been numerous wind forcing models used over the past few decades to model EBCs, particularly the California Current System. Early work included that of Pedlosky (1974) and Philander and Yoon (1982), who used steady wind stress and transient wind forcing, respectively. Carton (1984) and Carton and Philander (1984) investigated the response of reduced gravity models to realistic coastal winds. Another series of experiments were done by McCreary et al. (1987) utilizing a linear model with both transient and steady wind forcing in the California Current System. In all of these models, relatively weak currents $(5-10 \mathrm{~cm} / \mathrm{s})$ were generated but no eddies or filaments developed.

Batteen et al. (1989) used a primitive equation, multi-level model with biharmonic (rather than Laplacian, as used by the previous authors) heat and momentum diffusion which had both steady and meridionally varying wind forcing. In both cases, when the baroclinic/barotropic shear between the surface current and undercurrent became strong enough, meanders and filaments developed. Although this was the first EBC model to simulate meanders and filaments in the California Current System, no eddies were generated by the end of the 90-day experiments, presumably due to the relatively short simulation time.

The objective of this study is to extend the work of Batteen et al. (1989) by investigating the effects that both equatorward and climatological wind forcing have on the generation of not only currents, meanders, and filaments, but also eddies, in the Chile Current System. A slightly modified version of the high-resolution, multi-level, primitive equation model of Batteen et al. (1989) will be used to simulate the effects of wind stress 
in this region. Longer simulation times than 90 days will be used to allow the eddies to be generated and subsequently analyzed.

The organization of this study is as follows: Chapter II describes the numerical model, the forcing, the specific initial and experimental conditions, and the energy analysis technique. This technique is used to investigate the dynamical reasons for the generation of eddies in the Chile Current System. Chapter III includes an analysis of the results of the modeling experiments. along with a comparison of model results with available observations, while Chapter IV contains a summary. 


\section{THE MODEL}

\section{A. MODEL DESCRIPTION AND INITIAL CONDITIONS}

To investigate the role of wind forcing on the generation of currents. eddies, and filaments in the Chile EBC region, the wind stress fields, discussed below, were used to specify the wind forcing for a high-resolution, multi-level, primitive equation (PE) model of a baroclinic ocean on a $\beta$-plane. The model is based on the hydrostatic, Boussinesq, and rigid lid approximations. The governing equations are defined in Batteen et al. (1989). For the finite differencing, a space-staggered B-scheme (Arakawa and Lamb, 1977 ) is used in the horizontal. Batteen and Han (1981) have shown that this scheme is appropriate when the grid spacing is approximately on the same order as, or less than, the Rossby radius of deformation, which meets the criteria of this study. The horizontal grid spacing is $10 \mathrm{~km}$ alongshore and $9 \mathrm{~km}$ cross-shore, while the internal Rossby radius of deformation is $\sim 30 \mathrm{~km}$. In the vertical, the 10 layers are separated by constant $\mathrm{z}$ levels at depths of $13,46,98,182,316,529,870,1416,2283$, and $3656 \mathrm{~m}$. Consistent with Haney (1974), this spacing scheme concentrates more on the upper, dynamically active part of the ocean, above the thermocline.

The model domain (Figure 3) extends off the west coast of Chile, from $\sim 22.5^{\circ} \mathrm{S}$ to $35^{\circ} \mathrm{S}$ (1280 km alongshore), and from $\sim 72.5^{\circ} \mathrm{W}$ to $82.5^{\circ} \mathrm{W}$ (1152 km cross-shore). The eastern boundary of the model domain is closed, and has both the tangential and normal components of velocity set to zero. To isolate the role of wind forcing in the generation of eddies, the eastern boundary is modeled as a straight, vertical wall extending from the surface to $4500 \mathrm{~m}$ depth. These assumptions are justified since the Chilean coastline is relatively straight and smooth (see Figures 2 and 3), the continental shelf is relatively narrow, and the continental slope is steep, dropping from sea level to over $2000 \mathrm{~m}$ depth in a distance of less than $25 \mathrm{~km}$ from the coast (Ziegler et al. 1957). The northern, southern and western borders are open boundaries which use a modified version of the radiation boundary conditions of Camerlengo and O'Brien (1980). Some spatial smoothing is applied in the vicinity of the open boundaries. 
The model uses biharmonic lateral heat and momentum diffusion with the same choice of coefficients (i.e., $2.0 \times 10^{17} \mathrm{~cm}^{4} \mathrm{~s}^{-1}$ ) as in Batteen et al. (1989). Holland (1978) showed that the highly scale-selective biharmonic diffusion acts predominantly on submesoscales, while Holland and Batteen (1986) found that baroclinic mesoscale processes can be damped by Laplacian lateral heat diffusion. As a result, the use of biharmonic lateral diffusion should allow mesoscale eddy generation via barotropic (horizontal shear) and/or baroclinic (vertical shear) instability mechanisms. As in Batteen et al. (1989), weak $\left(0.5 \mathrm{~cm}^{2} \mathrm{~s}^{-1}\right)$ vertical eddy viscosities and conductivities are used. Bottom stress is parameterized by a simplified quadratic drag law (Weatherly, 1972), as in Batteen et al. (1989).

The method of solution is straightforward with the rigid lid and flat bottom assumptions because the vertically integrated horizontal velocity is subsequently nondivergent. The vertical mean flow can be described by a stream function which can be predicted from the vorticity equation, while the vertical shear currents can be predicted after the vertical mean flow is subtracted from the original equations. The other variables, i.e., temperature, density, vertical velocity and pressure, can be explicitly obtained from the thermodynamic energy equation, equation of state, continuity equation, and hydrostatic relation, respectively. Since density is primarily a function of temperature (e.g., see Wooster and Reid, 1963) and there are no major salinity sources or sinks (such as major rivers) in the region being modeled, effects of slinity changes on density are neglected.

An annual climatological temperature profile (Figure 4), centered at $\sim 28^{\circ} \mathrm{S}$ (corresponding to the middle of the model domain), based on Levitus (1982), was used to represent the initial temperature conditions for the model domain. An exponential curve was then used to approximate this. The form of the equation used was:

$$
T(z)=T_{B}+\Delta T e^{z / h}
$$

The approximation uses a length scale of $450 \mathrm{~m}$, and assumes $T_{B}=2^{\circ} C$ to be the temperature at great depth. $\Delta T=15^{\circ} \mathrm{C}$ is the change of temperature between the bottom 
and top of the profile. Figure 4 shows that the resulting temperature profile fits the annual climatological temperature profile. The exponential profile was used to provide initial values at each of the ten levels in the model.

\section{B. SPECIFIC EXPERIMENTAL DESIGN}

\section{Experiment 1: Constant Equatorward Winds}

In the first experiment, a constant equatorward wind stress of $1 \mathrm{dyne} / \mathrm{cm}^{2}(\sim 830$ $\mathrm{cm} / \mathrm{s}$ ) is applied to all grid points within the domain, except for a small band at the northern and southern ends, where no wind forcing is applied. McCreary (1981) and Batteen et al. (1989) demonstrated that this technique allowed for the propagation of coastal Kelvin waves, which in turn allowed for the creation of an undercurrent. Because the winds are predominantly equatorward all year off Chile, this experiment should isolate the effects of upwelling favorable winds on the Chile Current System.

\section{Experiment 2: Variable Climatological Winds}

In Experiment 2, climatological winds are used to simulate the temporal and spatial wind variations that have been observed off the coast of Chile. The winds used to force the model are from the European Center for Medium-Range Weather Forecasts (ECMWF) (Trenberth et al. 1990) and have been provided by the National Center for Atmospheric Research. Winds were extracted from world wide mean monthly wind velocities that were provided at 2.5 degree spacing for the years 1980 to 1989 along with 120 month climatology for the area of study. This data was linearly interpolated in space and then in time to provide daily forcing at all of the grid points.

An example of the wind fields used can be seen in Figure 5, which shows the annual migration of the South Pacific Subtropical High from the south in the austral summer (Figure $5 \mathrm{~d}$ ), to the north in the austral winter (Figure $5 \mathrm{~b}$ ), the effects of which are discussed in the next chapter. These wind field patterns are consistent with those of Bakun and Nelson (1991).

To isolate the effects of wind forcing in this process-oriented study, the net heat flux at the sea surface should initially be zero. In this way, any heat flux that is 
discernible will have been generated by an increase or decrease of sea surface temperature resulting from wind forcing effects (Batteen et al. 1989). To accomplish this, an initial air temperature is chosen that forces the net flux of longwave radiation, sensible heat, and latent heat to zero. This air temperature is then used in the model for both experiments. Any subsequent surface heat flux forcing is therefore a secondary effect of the changes to sea surface temperature due to the wind forcing.

\section{ENERGY ANALYSIS TECHNIQUE}

The energy technique used is the same as that used and described in Batteen et al. (1992b), and is based on that of Han (1975) and Semtner and Mintz (1977). This analysis is done to gain a better understanding of the types of energy transfer during unstable flow in the Chile Current System. A brief summary of the method follows.

Kinetic energy is calculated for the horizontal components. After quasi-steady state is reached where the total kinetic energy is nearly constant, mean and eddy kinetic energies are calculated using the averaged sum of squared mean and eddy horizontal fields, respectively. Next, the available potential energy is calculated and used to determine when a quasi-steady state is reached and when statistics should be collected. Then, both mean and eddy available potential energies are computed. The barotropic and baroclinic energy transfers, defined in Batteen et al. (1992b), are used to argue for the type of instability mechanism (e.g., barotropic, baroclinic, or mixed) which leads to the initial eddy generation in each experiment. 


\section{RESULTS OF THE EXPERIMENTS}

Experiments 1 and 2 study the role of wind forcing in the formation of currents and eddies in the Chile Current System. Experiment 1 uses steady equatorward winds, while Experiment 2 uses climatological average (1980-1989) winds.

\section{A. EXPERIMENT 1 -- CONSTANT EQUATORWARD WINDS}

Experiment 1 was forced with a constant equatorward wind stress $\left(1 \mathrm{dyne} / \mathrm{cm}^{2}\right)$, which was uniform in both the alongshore and cross-shore directions. As expected, the equatorward wind forcing resulted in an equatorward surface current along most of the coast (Figure 6a). The current's velocities ranged from $\sim 10$ to $30 \mathrm{~cm} / \mathrm{s}$ throughout the duration of the experiment. The coastal jet axis was within $\sim 50 \mathrm{~km}$ of the coast and extended to $\sim 150 \mathrm{~m}$ depth (Figure 7).

A poleward undercurrent with a core velocity of $\sim 8 \mathrm{~cm} / \mathrm{s}$ at $\sim 100$ to $150 \mathrm{~m}$ depth is also seen in Figure 7 below the surface current. The undercurrent extends along the entire coast and is confined to $\sim 50 \mathrm{~km}$ of the coast. Typical velocities for the undercurrent ranged from $\sim 5$ to $15 \mathrm{~cm} / \mathrm{s}$ throughout the duration of the experiment.

Along with the equatorward surface current, upwelling also occurred, as seen in Figure 8a. Meanders in the equatorward surface current formed by model day 45 and are evident in both the velocity and temperature plots (Figures $6 \mathrm{~b}$ and $8 \mathrm{~b}$, respectively). As the meanders intensify, cold upwelling filaments develop along the coast and subsequently extend farther offshore (Compare day 45 in Figure $8 \mathrm{~b}$ with day 75 in Figure $8 \mathrm{c}$ to see the time evolution ).

More detailed analysis was performed to determine the type of instability mechanism that could generate the meander features. Barotropic instability can result from horizontal shear, while baroclinic instability can result from vertical shear in the current. As Figure 7 shows, there is considerable horizontal and vertical shear between the equatorward surface current and the poleward undercurrent. As a result, both types of instabilities (mixed), can be present simultaneously. Energy transfer calculations which consist of barotropic (mean kinetic energy to eddy kinetic energy) and baroclinic (eddy potential energy to eddy kinetic energy) components were performed for the time period 
(i.e., days 39-60) during which the meanders developed. The results for the instability analyses (Figure 9) show that both barotropic (Figure 9a) and baroclinic (Figure 9b) instabilities were present in the coastal region of the domain.

By model day 105, the meanders began to form cold core, cyclonic eddies and warm core, anticyclonic eddies, as seen in Figures $6 \mathrm{c}$ and $8 \mathrm{~d}$, due to vertical and horizontal shear instabilities between the equatorward jet and the poleward undercurrent. The eddies initially appeared to be about $100 \mathrm{~km}$ in diameter and extended about 100-200 $\mathrm{km}$ off the coast. Subsequently, the eddies propagated farther offshore with speeds of $\sim 5$ $10 \mathrm{~km} /$ day, consistent with Rossby wave propagation speeds.

At the end of the model year, the coastal jet, undercurrent (not shown), meanders and eddies (which have propagated further offshore) are still present (Figure 6d). Upwelling and filaments are also still discernible (Figure 8e). These features are due to the constant equatorward wind forcing, which provides a continual source for the generation of the currents and the subsequent development (via barotropic/baroclinic instability mechanisms) of meanders, filaments, and eddies. Longer experimental runs of three more years (not shown) show that these features continue to be generated and maintained in the Chile Current System.

\section{B. EXPERIMENT 2 -- VARIABLE CLIMATOLOGICAL WINDS}

Experiment 2 was forced with the climatological average (1980-1989) winds (Figure 5). An equatorward surface current was observed all along the coast by model day 30 (Figure 10a) due to the prevailing equatorward winds. The current's velocities ranged from $\sim 10$ to $30 \mathrm{~cm} / \mathrm{s}$ throughout the experiment. The coastal jet axis was within $\sim 50 \mathrm{~km}$ of the coast and extended to $\sim 250 \mathrm{~m}$ depth (Figure 11). These results are similar to Experiment 1, as expected, since the winds are still predominantly equatorward.

Unlike Experiment 1, an equatorward surface current also develops $\sim 200 \mathrm{~km}$ offshore between days 30 and 45 in the poleward end of the model domain (Figure 10b). The core of the current extends to a depth of $\sim 250 \mathrm{~m}$ depth (Figure 11). From days 90 to 150 , it extends along the entire coast (e.g., see Figure 10c). From days 165 to 210 , it is present only in the equatorward end of the domain (e.g., see Figure 10d). It subsequently 
redevelops in the poleward end of the domain by day 225 (Figure 10e). The location of this feature appears to migrate with the South Pacific Subtropical High, which migrates from the south in the austral summer (Figure $5 \mathrm{~d}$ ) to the north in the austral winter (Figure $5 b)$.

In addition to the coastal and offshore branches of the surface equatorward currents, a poleward undercurrent with a core velocity of $\sim 3 \mathrm{~cm} / \mathrm{s}$ at $\sim 150 \mathrm{~m}$ depth is also seen in Figure 11 below the coastal, equatorward current. As in Experiment 1, the undercurrent extends along the entire coast and is confined to $-50-75 \mathrm{~km}$ of the coast. Typical velocities for the undercurrent range from 3 to $15 \mathrm{~cm} / \mathrm{s}$ throughout the duration of the experiment.

Along with the equatorward surface currents, upwelling also occurs, as seen in the surface temperature field (Figure 12a). The coastal location of colder temperatures due to upwelling appears to migrate from poleward (Figure 12a) to equatorward (Figure 12d), possibly following the migration of the South Pacific Subtropical High.

Meanders in the equatorward surface current formed by model day 135 in the equatorward end of the model domain, as seen in the velocity and temperature plots (Figures $10 \mathrm{c}$ and 12b, respectively). The results for the instability analysis (Figure 13) for the time period (i.e., days 120-135) during which the meanders developed, show that, although both types of instabilities are present in the coastal region of the model domain, barotropic instability (Figure 13a) is dominant over baroclinic (Figure 13b) instability in the equatorward end of the model domain.

By model day 180, the meanders begin to form cold core, cyclonic eddies as seen in the temperature and velocity plots (Figures $10 \mathrm{~d}$ and $12 \mathrm{c}$, respectively), due to vertical and horizontal shear instabilities between the equatorward jet and the poleward undercurrent. By model day 225, the meanders also begin to form warm, anticyclonic eddies, as seen in the temperature and velocity plots (Figure $12 \mathrm{~d}$ and 10e, respectively). Both the cyclonic and anticyclonic eddies initially appear to be about $100 \mathrm{~km}$ in diameter and extend about $200 \mathrm{~km}$ off the coast. As in Experiment 1, the eddies propagate farther offshore with speeds of $\sim 5-10 \mathrm{~km}$ /day. Unlike Experiment 1, as the eddies move 
offshore, they become embedded in the oceanic branch of the surface equatorward current, which veers further offshore with time (see Figures $10 \mathrm{e}$ and $10 \mathrm{f}$, for example).

At the end of the model year these features are still discernible. Upwelling and filaments are still present (Figure 12e). Longer experimental runs of three more years (not shown) show that these features continue to be generated and maintained in the Chile Current System.

The coastal branch of the equatorward surface current, the undercurrent, upwelling, meanders, filaments, and eddies are due to the predominantly equatorward wind forcing. These features are similar to Experiment 1. Unlike Experiment 1, an offshore branch of the equatorward surface current is also generated. This feature originates in the vicinity of the South Pacific Subtropical High and its location migrates with the location of the South Pacific Subtropical High.

\section{COMPARISON OF MODEL RESULTS WITH OBSERVATIONS}

A comparison of model results with available observations was carried out to see if model simulations of the currents and other features were consistent with the observed data for the Chile Current System. Table 1 highlights the primary features in the Chile Current System. It also lists the specific characteristics (if available observations exist for them) for each feature along with the corresponding model result for each experiment.

Table 1 shows that both experiments successfully simulate most of the observed features of the Chile Current System, i.e., the coastal equatorward surface current (the coastal CPC), the coastal poleward undercurrent (the PCU), upwelling, filaments, meanders, and eddies. Consistent with observations, the experiments also successfully simulate the magnitudes of the average velocity, core depth, and mass transport for the coastal $\mathrm{CPC}$, and the average velocity, core depth, offshore distance, and mass transport for the PCU. Only Experiment 2 successfully simulates the offshore equatorward surface current (the offshore $\mathrm{CPC}$ ). In addition, Experiment 2 also successfully simulates the magnitudes of the average velocity, core depth, and offshore distance for the offshore $\mathrm{CPC}$. 


\section{SUMMARY}

This study used a high resolution, multi-level, primitive equation model to investigate the role of wind forcing in the formation of currents and eddies in the Chile Current System. Experiment 1 used steady equatorward winds, while Experiment 2 used climatological average (1980-1989) winds obtained from the European Center for Medium-Range Weather Forecasts (ECMWF).

The model results of both experiments showed the development of a coastal equatorward surface current and coastal poleward undercurrent. Due to barotropic/baroclinic instability, the coastal currents became unstable, resulting in the generation of meanders near the coast. Upwelling also occurred and, as the meanders intensified, cold upwelling filaments developed along the coast and subsequently extended farther offshore. In time, the meanders formed both cold core, cyclonic eddies and warm core, anticyclonic eddies, which subsequently propagated farther offshore with speeds consistent with Rossby wave propagation speeds. By the end of the model year, all of these features were still present, as expected, since the predominantly equatorward winds used in both experiments provide a continual source for the generation of the currents and the subsequent development of upwelling, meanders, filaments, and eddies.

Only the model results of Experiment 2 showed the development of an offshore equatorward surface current. The location of this feature appeared to migrate with the South Pacific Subtropical High, which migrates from the south in the austral summer to the north in the austral winter.

A comparison of model results with available observations showed that both experiments successfully simulated most of the observed features of the Chile Current System, i.e., the coastal CPC, the PCU, upwelling, filaments, meanders, and eddies. Only Experiment 2 successfully simulated the offshore $\mathrm{CPC}$, which is another observed feature of the Chile Current System.

The results from these experiments strongly support the hypothesis that wind forcing can be a significant generation mechanism for currents, upwelling, filaments, meanders, and eddies in the Chile Current System. The results of this study may also be 
applicable to other $\mathrm{EBC}$ regions which have predominantly equatorward wind forcing, such as the central and southern regions of the California Current System. 


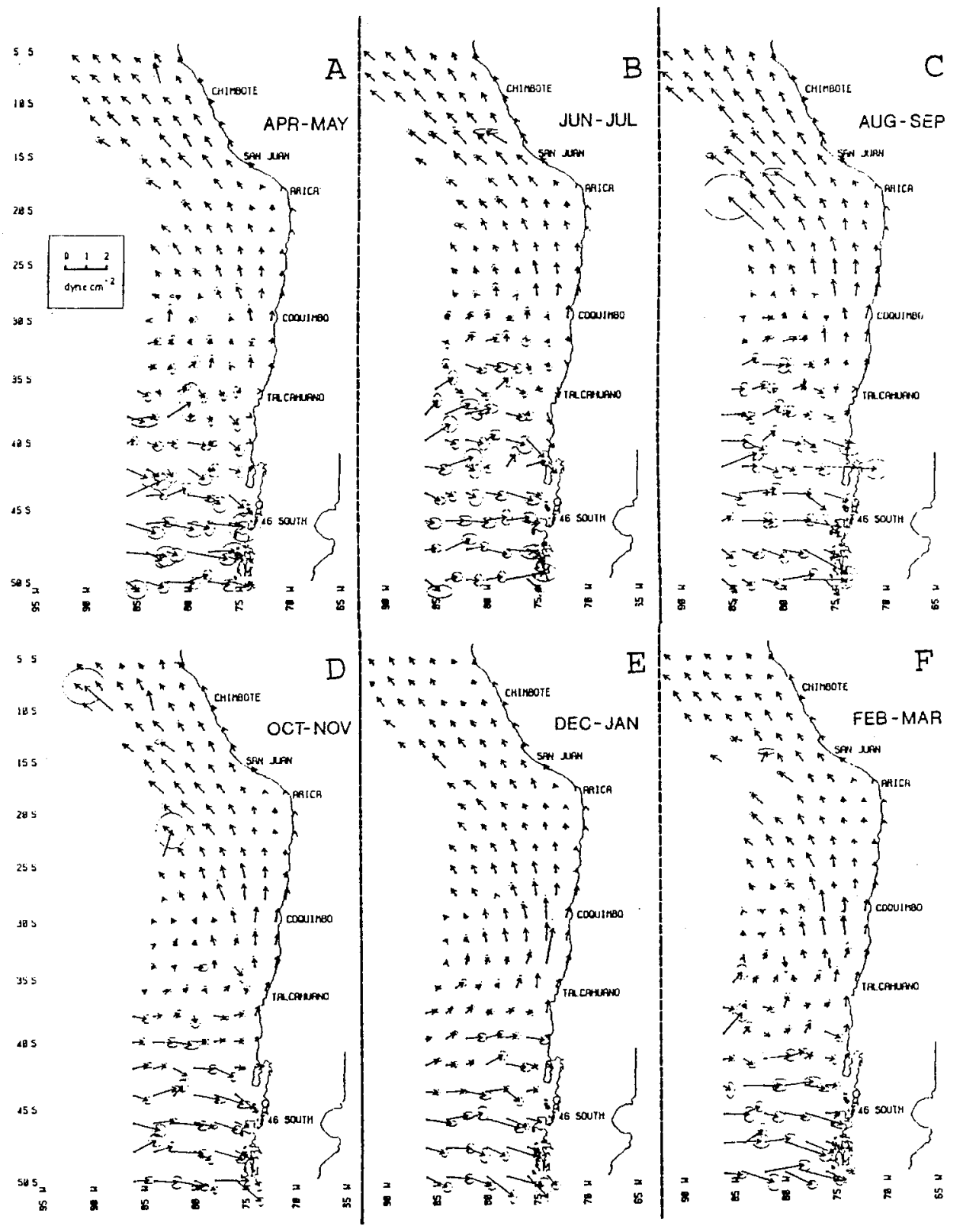

Figure 1. Wind stress fields for the time period (a) April-May, (b) JuneJuly, (c) August-September, (d) October-November, (e) DecemberJanuary, and (f) February-March. Vectors are scaled in units of $d y n e / \mathrm{cm}^{2}$. Ellipses show areas of large standard errors (after Bakun and Nelson, 1991). 


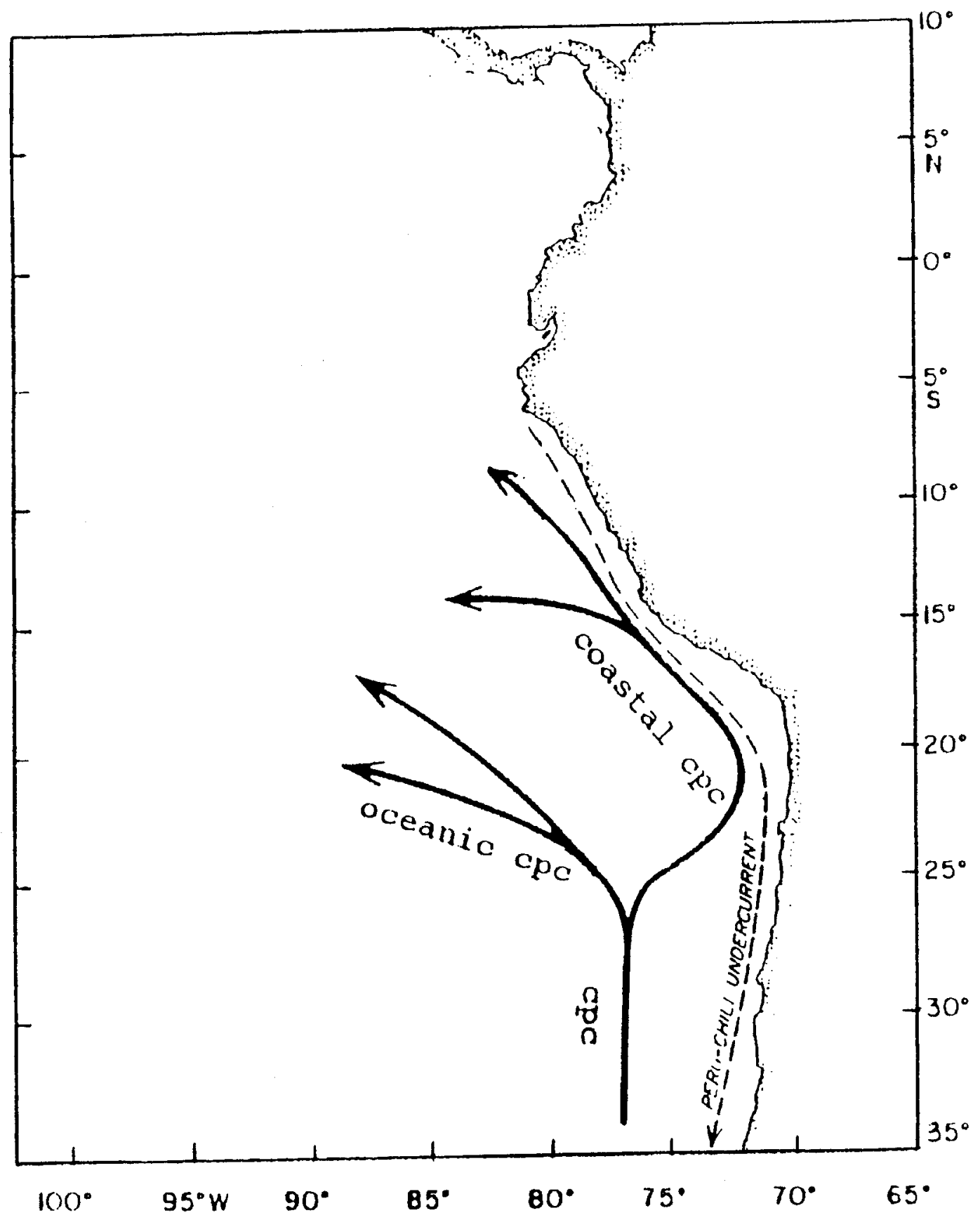

Figure 2. Generalized circulation schematic for the Chile Current System (after Codispoti et al. 1989): The broad equatorward Chile-Peru Current (CPC) (solid lines) separates into two branches: the coastal CPC and the oceanic CPC. The coastal CPC overlies the poleward undercurrent, known as the Peru-Chile Undercurrent (dashed line). 


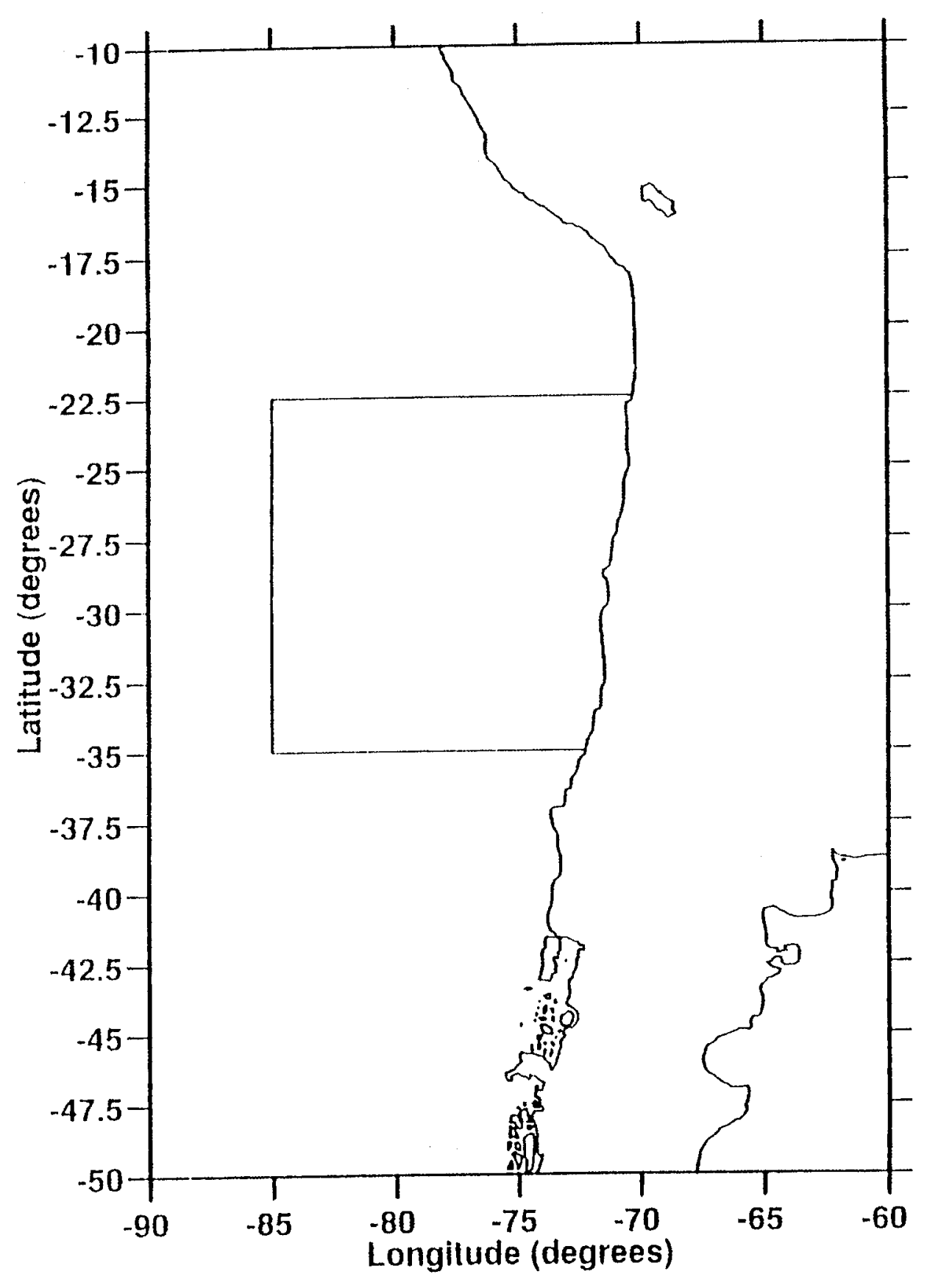

Figure 3. Model Domain: Area of study is a $1152 \mathrm{~km}$ (cross-shore) by $1280 \mathrm{~km}$ (alongshore) box off the coast of Chile. 


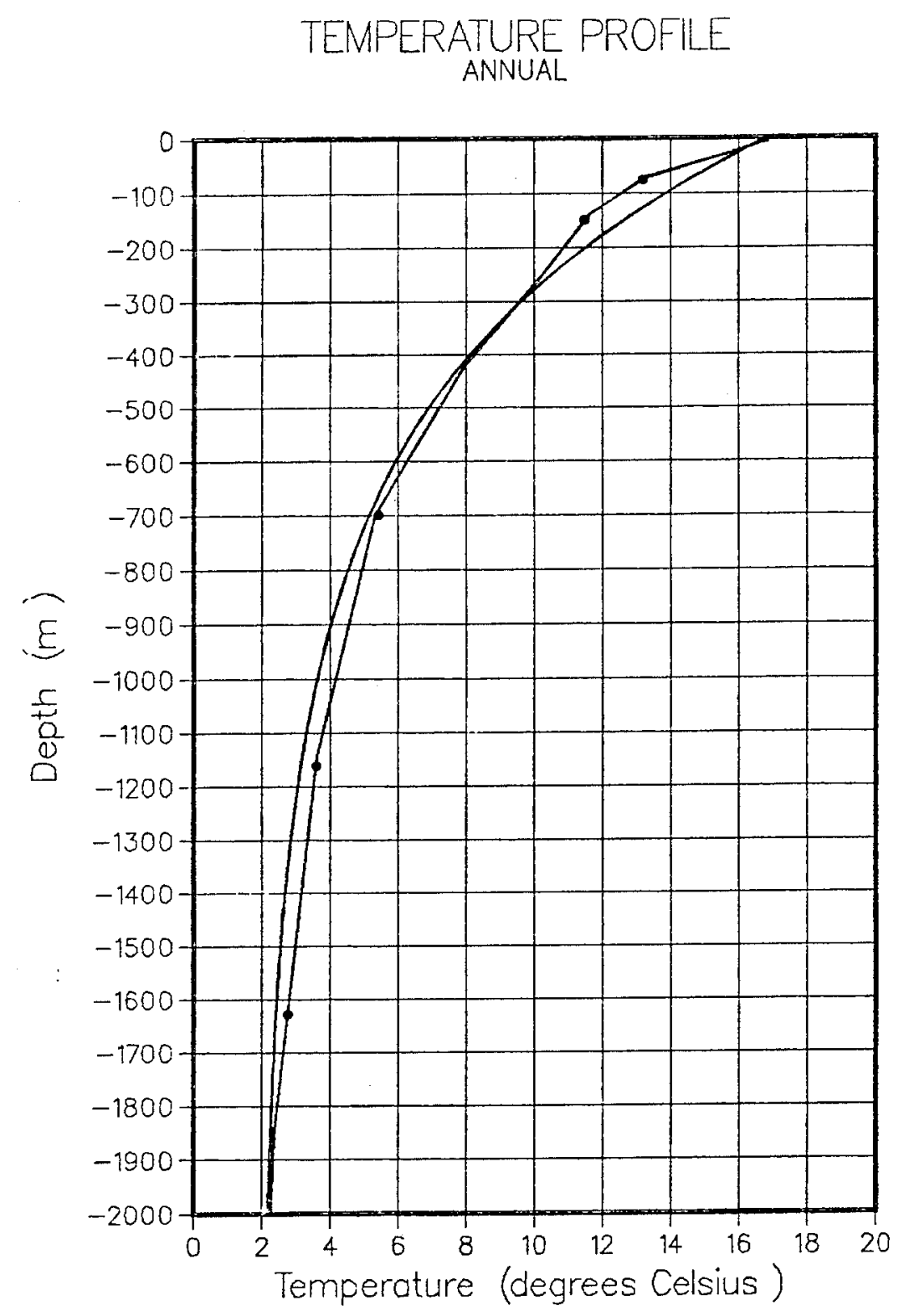

Figure 4. Temperature profile (i.e., temperature in degrees Celsius versus depth in meters) used in the model: A smooth exponential curve (solid line) was used to approximate the climatological temperature profile (solid line with small circles) computed from Levitus (1982). 

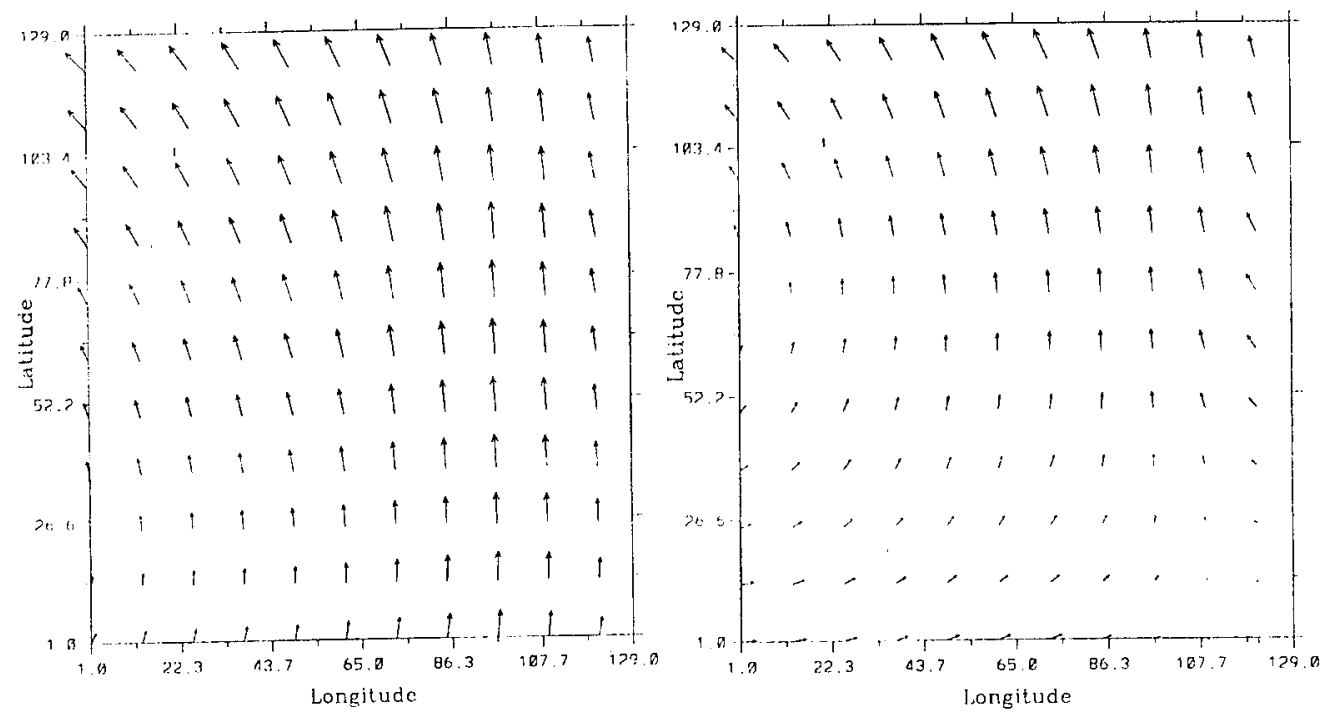

(a)

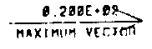

(b)

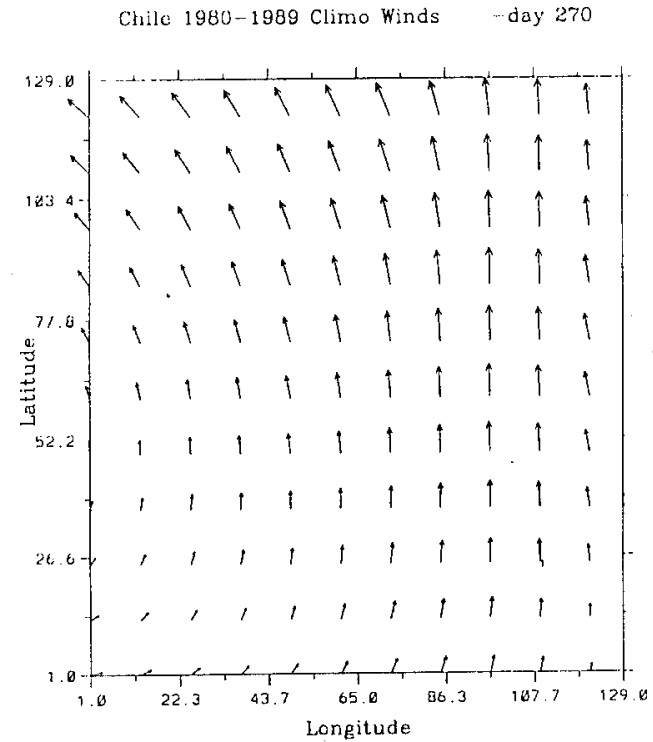

(c)

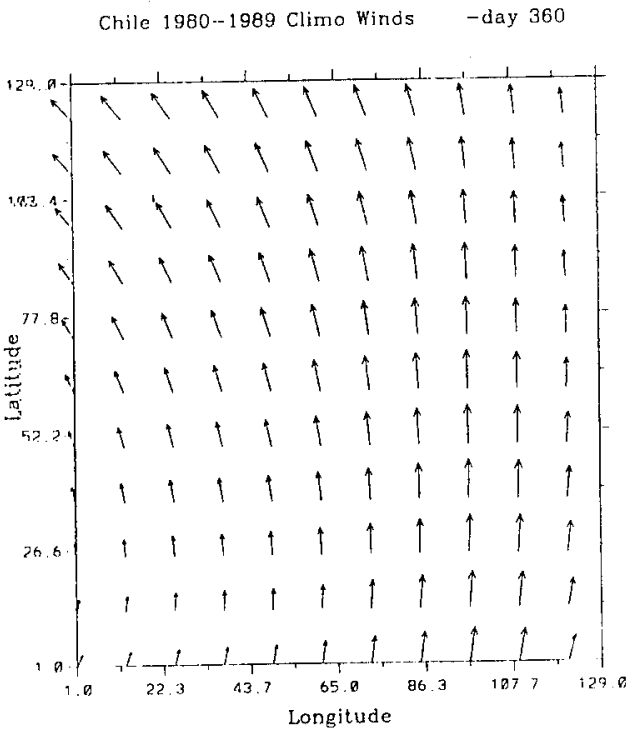

(d)

Figure 5. Climatological (1980 - 1989) ECMWF winds in $\mathrm{m} / \mathrm{s}$ : (a) day 90 , (b) day 180 , (c) day 270 , (d) day 360. The latitudinal grid point 1 (129) corresponds to $35^{\circ} \mathrm{S}\left(22.5^{\circ} \mathrm{S}\right)$. The longitudinal grid point 1 (129) corresponds to $82.5^{\circ} \mathrm{W}\left(72.5^{\circ} \mathrm{W}\right)$. Maximum wind vector is $20 \mathrm{~m} / \mathrm{s}$. 

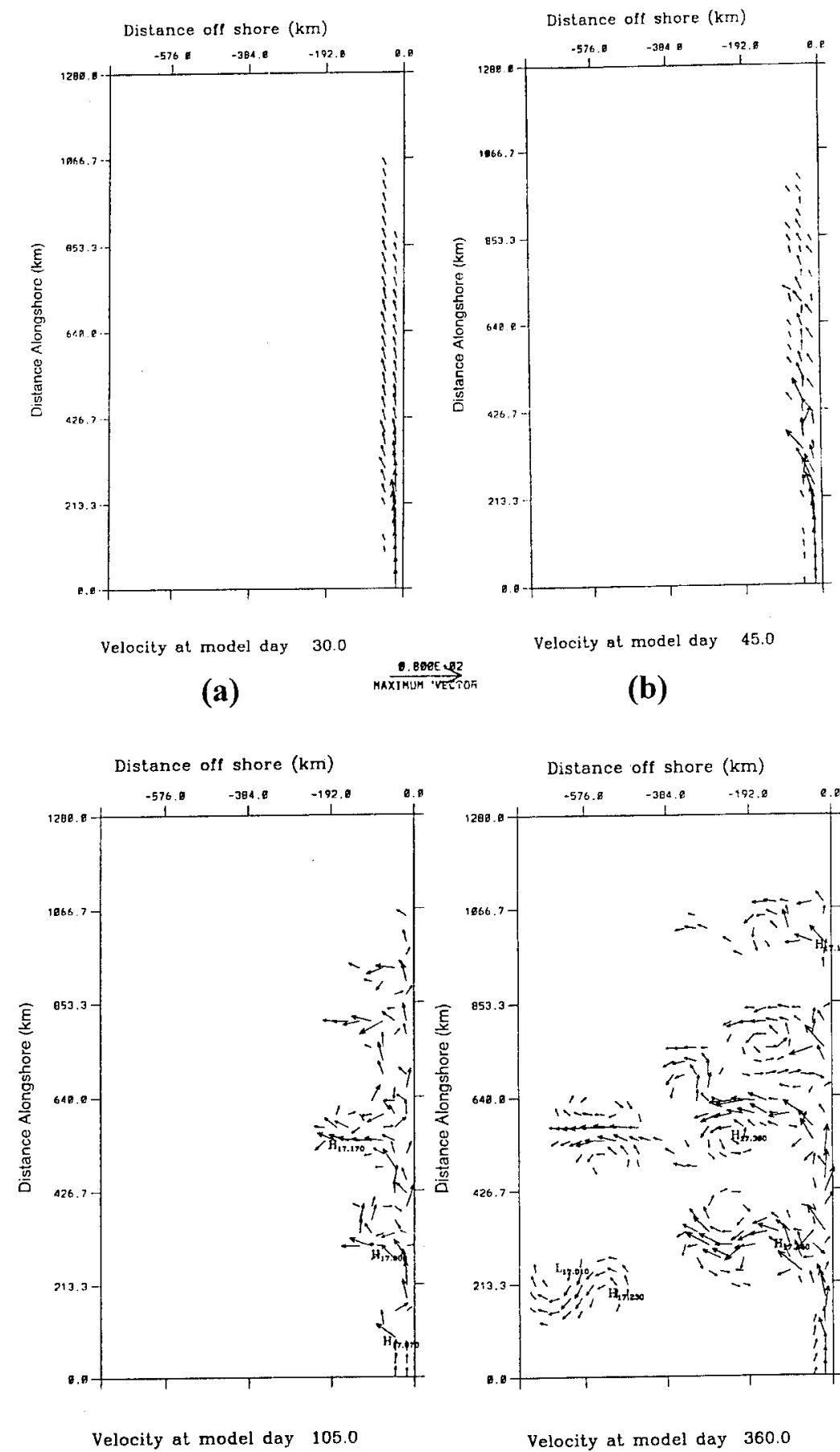

(c)

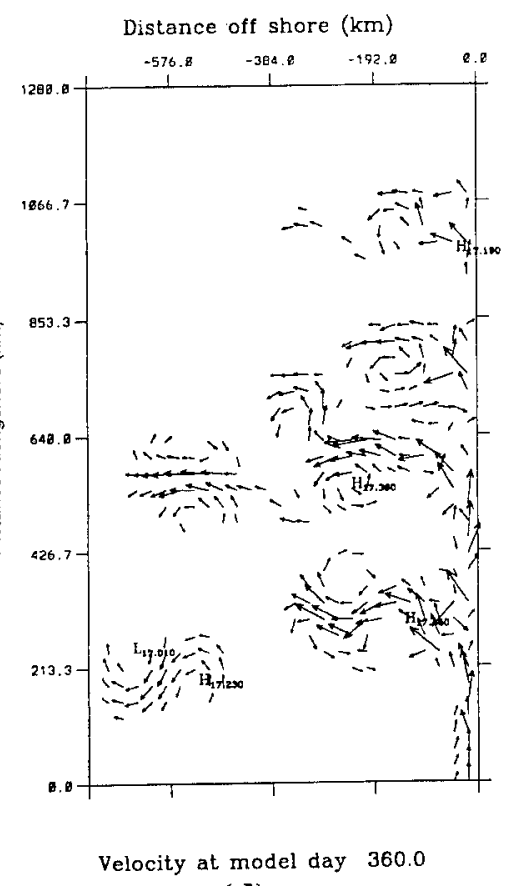

(d)

Figure 6. Experiment 1: Surface velocity vectors in the coastal region at days (a) 30 , (b) 45 , (c) 105 , and (d) 360 . To avoid clutter, velocity vectors are plotted at every third grid point in both the cross-shore and alongshore directions, and velocities less than $5 \mathrm{~cm} / \mathrm{s}$ are not plotted. The numbers associated with the highs in Figures $6 \mathrm{c}$ and $6 \mathrm{~d}$ correspond to temperature, not velocity. Maximum current vector is $80 \mathrm{~cm} / \mathrm{s}$. 


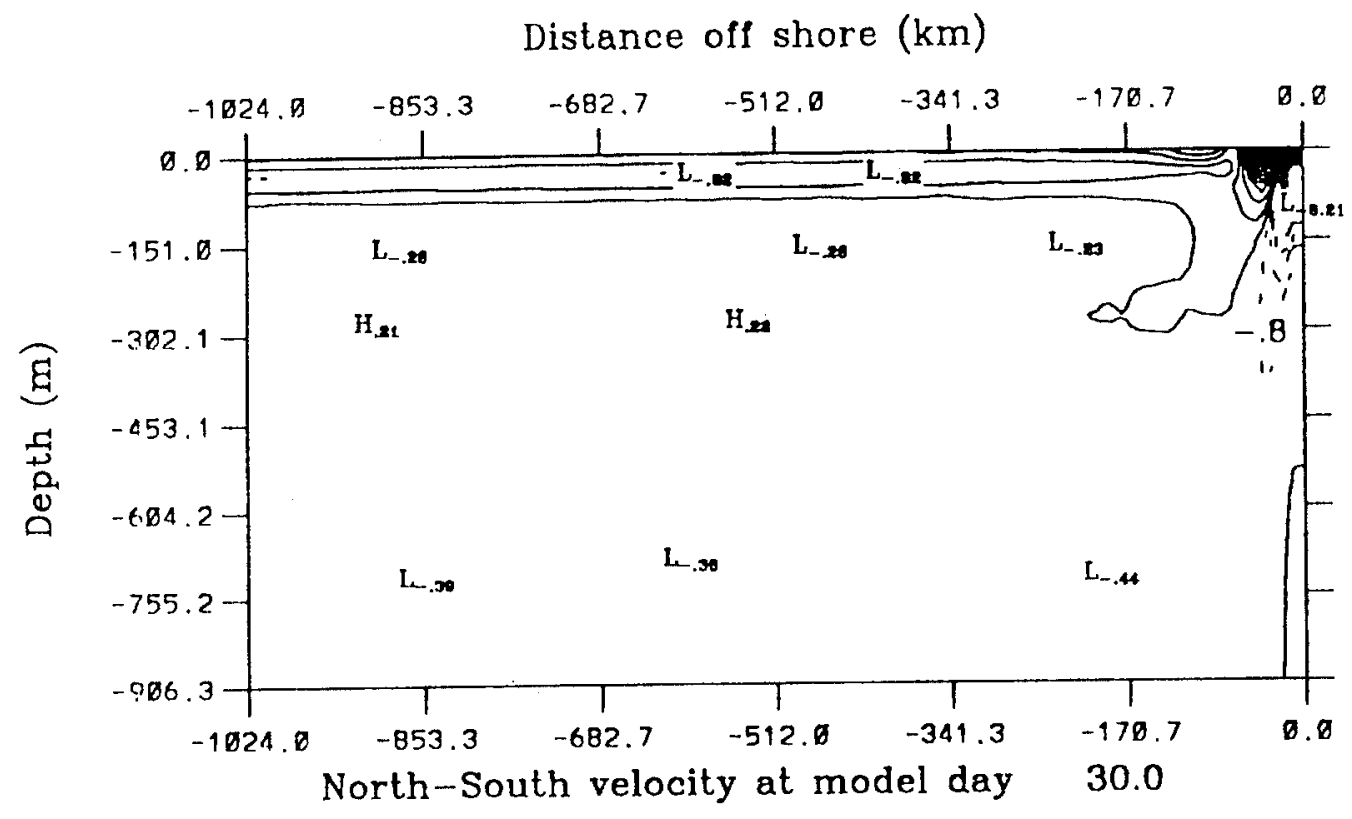

Figure 7. Experiment 1: Cross-shore section at $\mathrm{y} \sim 640 \mathrm{~km}\left(\sim 29^{\circ} \mathrm{S}\right)$ of the meridional component of velocity at day 30 . Solid lines indicate equatorward flow, while dashed lines indicate poleward flow. The contour interval is $2 \mathrm{~cm} / \mathrm{s}$. The maximum equatorward velocity is $\sim 20 \mathrm{~cm} / \mathrm{s}$ at the surface, $\sim 50 \mathrm{~km}$ off the coast. 

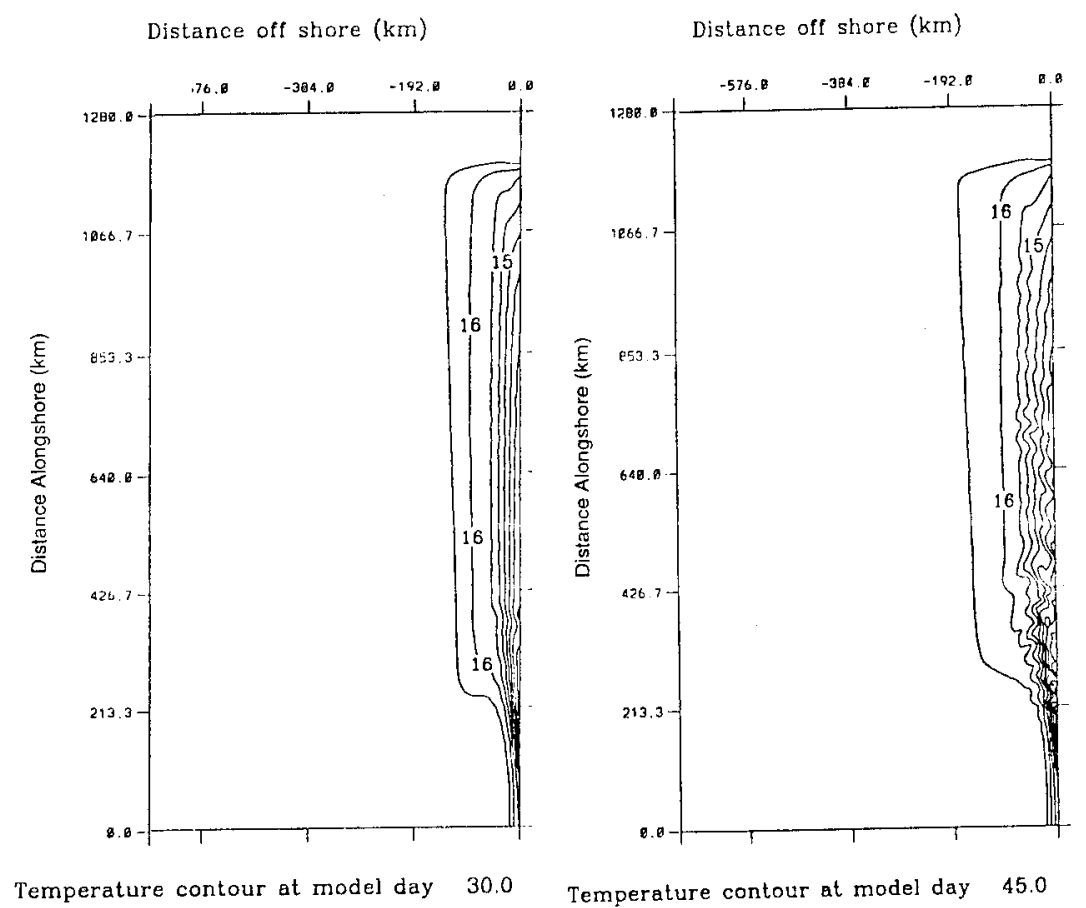

(a)

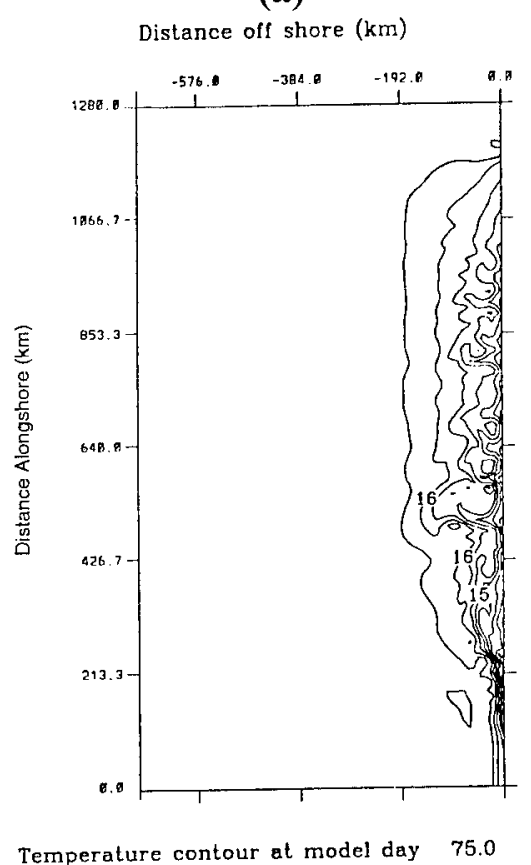

(c)

(b)



Figure 8. Experiment 1: Surface temperature in the coastal region at days (a) 30 , (b) 45 , (c) 75 , (d) 105 , and (e) 360 . The contour interval is $0.5^{\circ} \mathrm{C}$. The temperature decreases toward the coast. Note the existence of upwelling and meanders. 


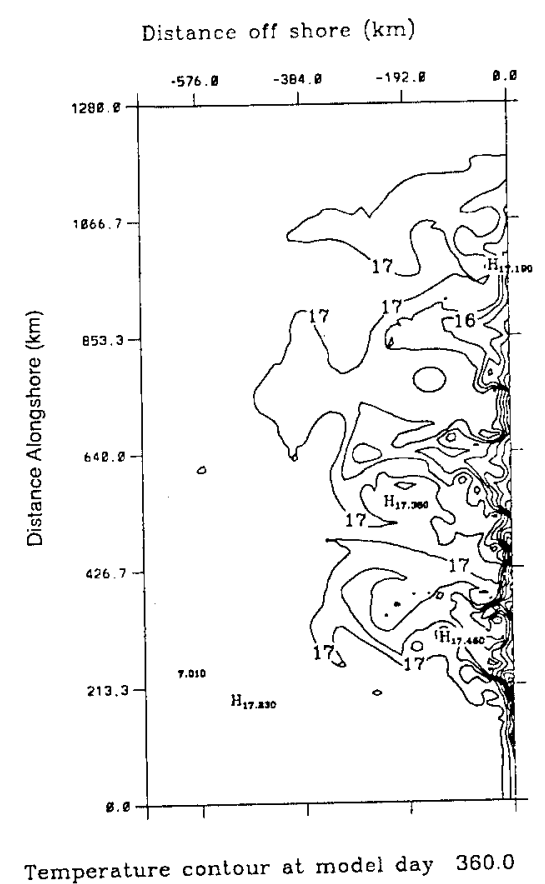

(e) 


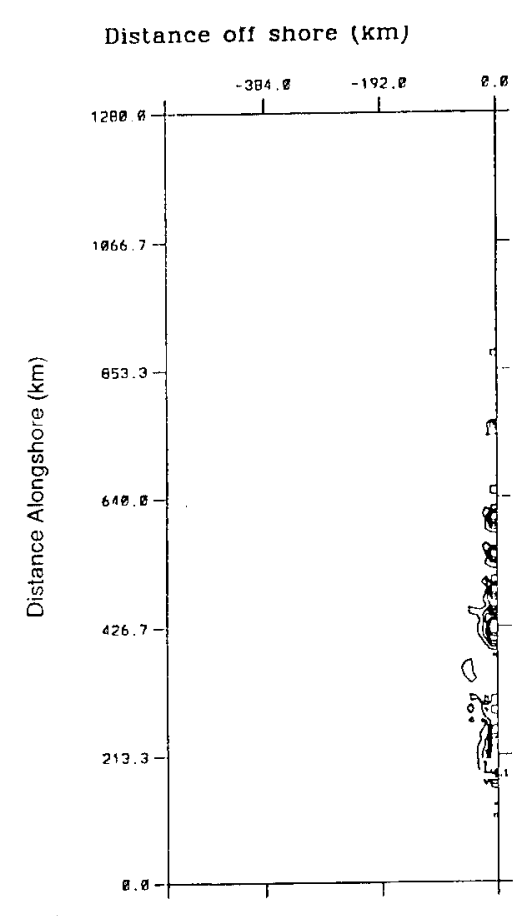

Mean kinetic energy to eddy kinetic energy

(a)

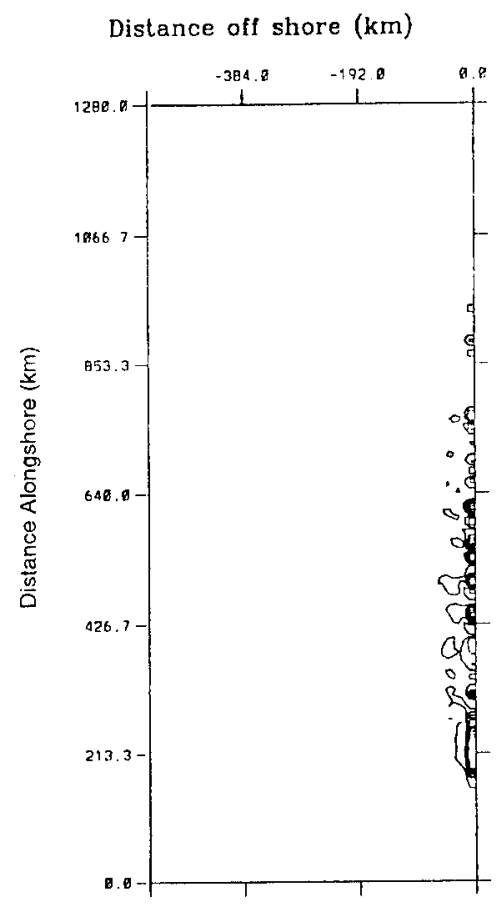

(b)

Figure 9. Experiment 1: Energy transfers in the coastal region of (a) mean to eddy kinetic energy (i.e., barotropic energy transfer) and (b) eddy potential to eddy kinetic energy (i.e., baroclinic energy transfer) for model days 39 to 60 . The contour interval is $10 \mathrm{ergs} \mathrm{cm}^{-3} \mathrm{~s}^{-1}$. 

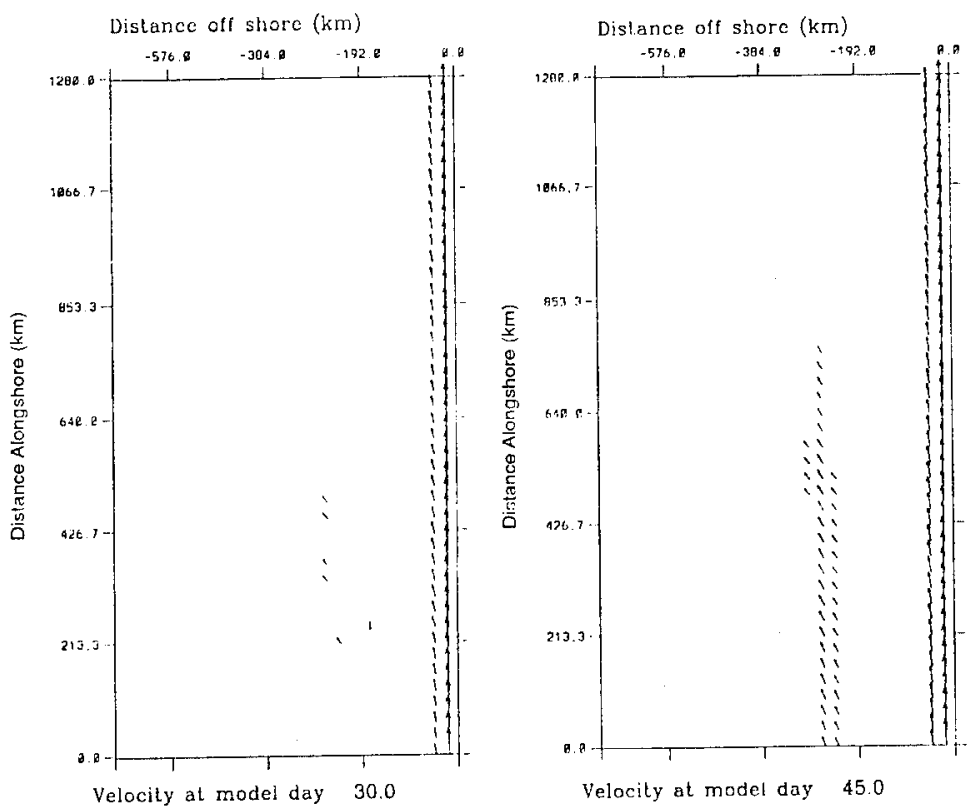

(a)

(b)

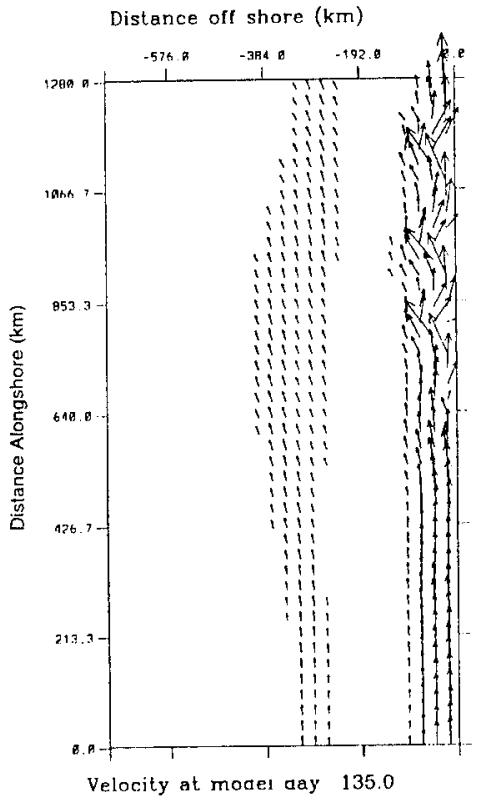

(c)

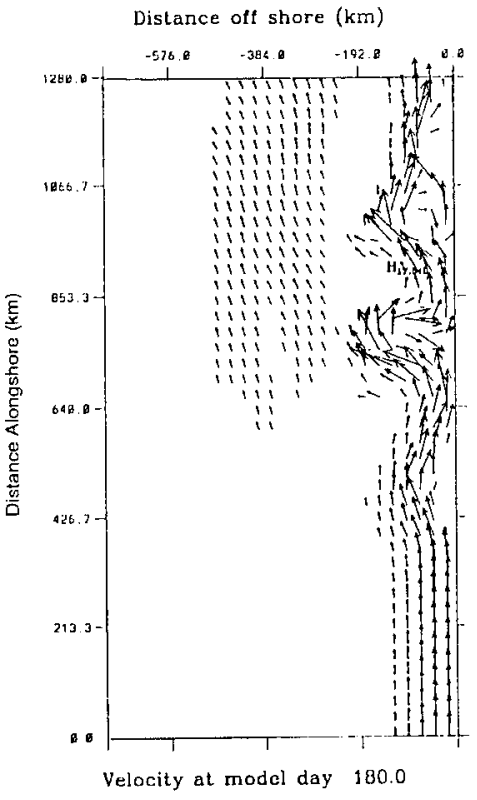

(d)

Figure 10. Experiment 2: Surface velocity vectors in the coastal region at days (a) 30 , (b) 45 , (c) 135 , (d) 180 , (e) 225 , and (f) 360 . To avoid clutter, velocity vectors are plotted at every third grid point in both the cross-shore and alongshore directions, and velocities less than $5 \mathrm{~cm} / \mathrm{s}$ are not plotted. The numbers associated with the highs in Figures 10d and $10 \mathrm{f}$ correspond to temperature, not velocity. Maximum current vector is $80 \mathrm{~cm} / \mathrm{s}$. 


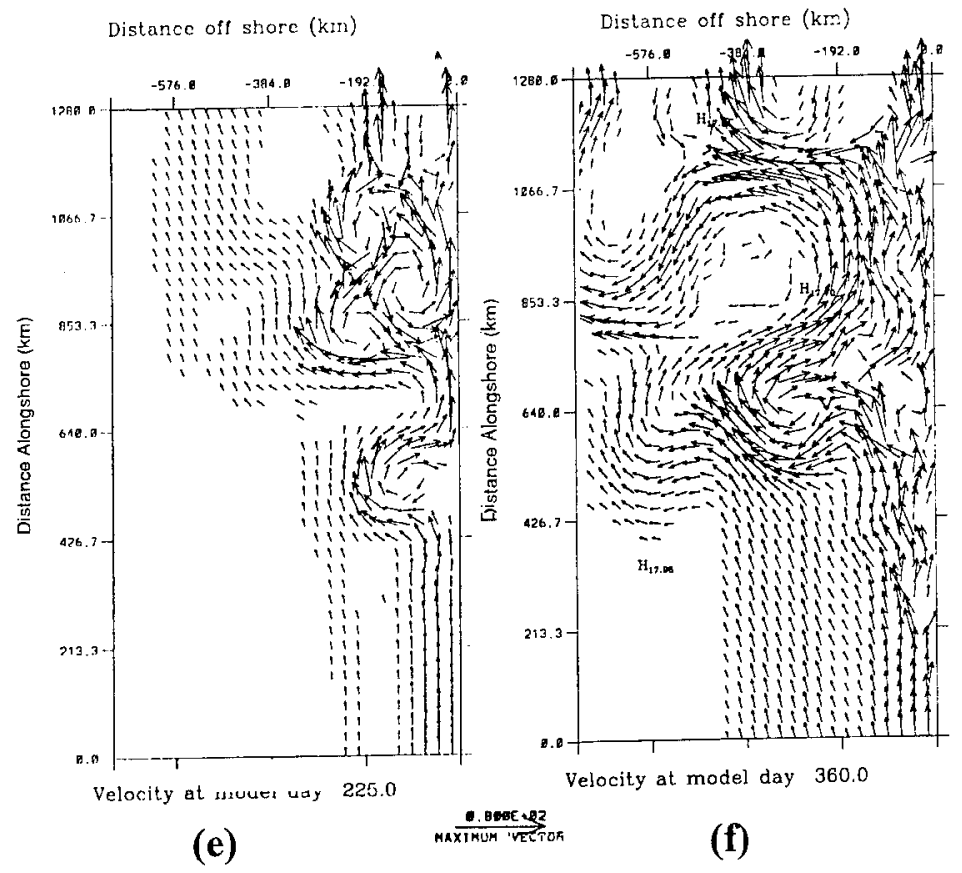




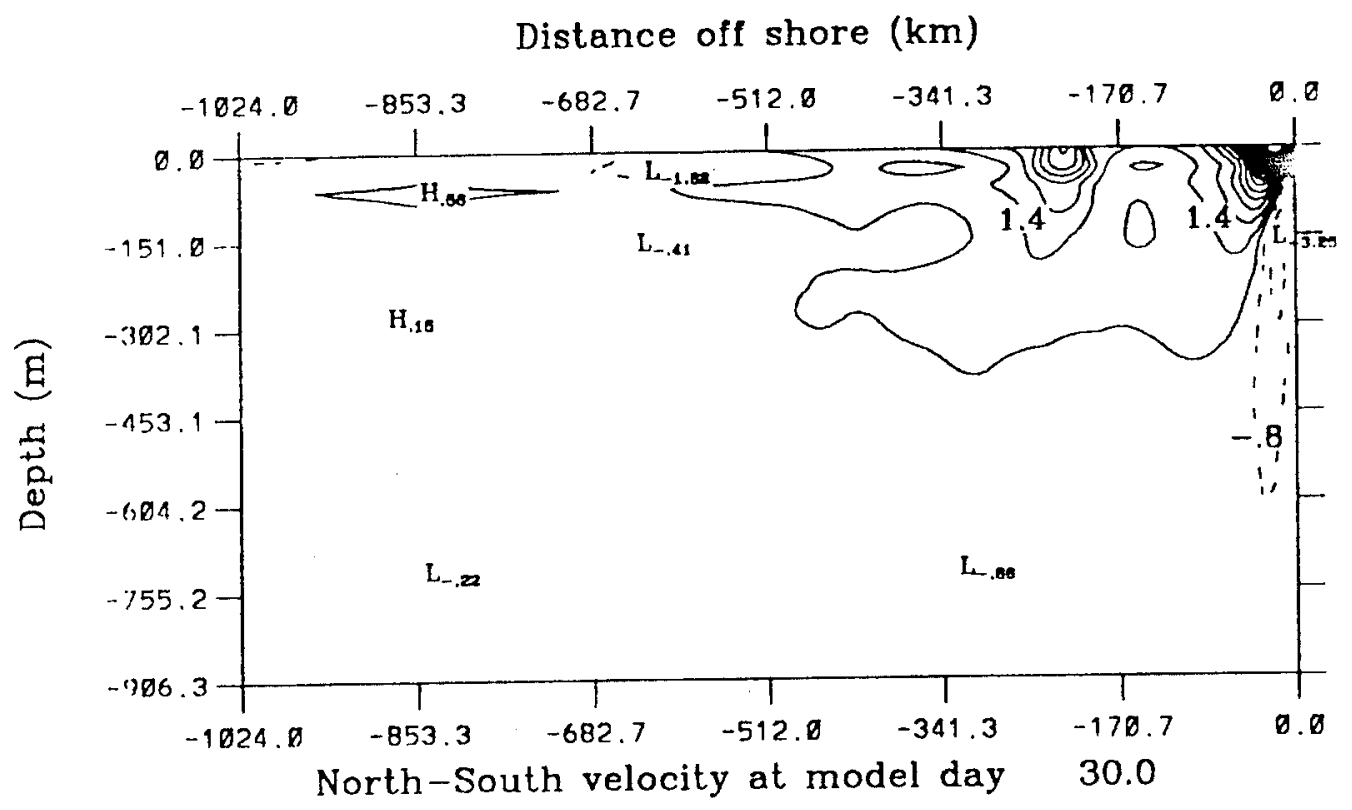

Figure 11. Experiment 2: Cross-shore section at $\mathrm{y} \sim 640 \mathrm{~km}\left(\sim 29^{\circ} \mathrm{S}\right)$ of the meridional component of velocity at day 30. Solid lines indicate equatorward flow, while dashed lines indicate poleward flow. The contour interval is $2 \mathrm{~cm} / \mathrm{s}$. The maximum equatorward velocity is $\sim 20 \mathrm{~cm} / \mathrm{s}$ at the surface, $\sim 50 \mathrm{~km}$ off the coast. 


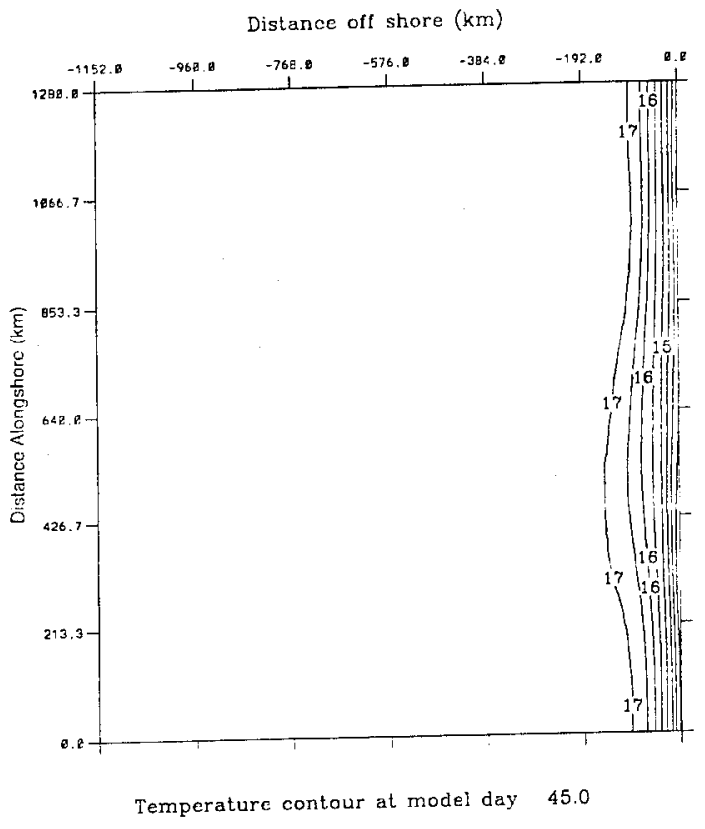

(a)



(c)



(b)

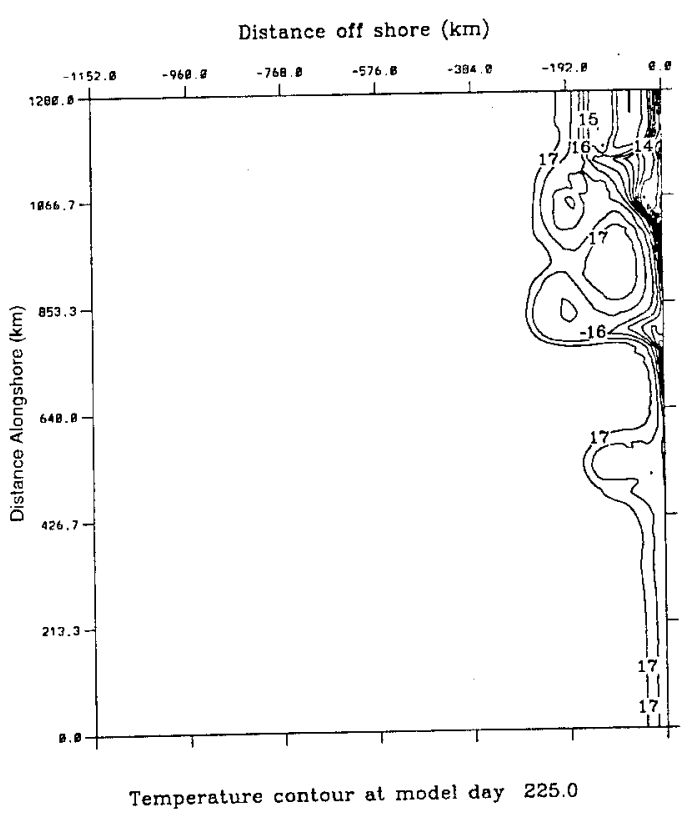

(d)

Figure 12. Experiment 2: Surface temperature at days (a) 45, (b) 135, (c) 180 , (d) 225 , and (e) 360 . The contour interval is $0.5^{\circ} \mathrm{C}$. The temperature decreases toward the coast. Note the existence of upwelling and meanders. 


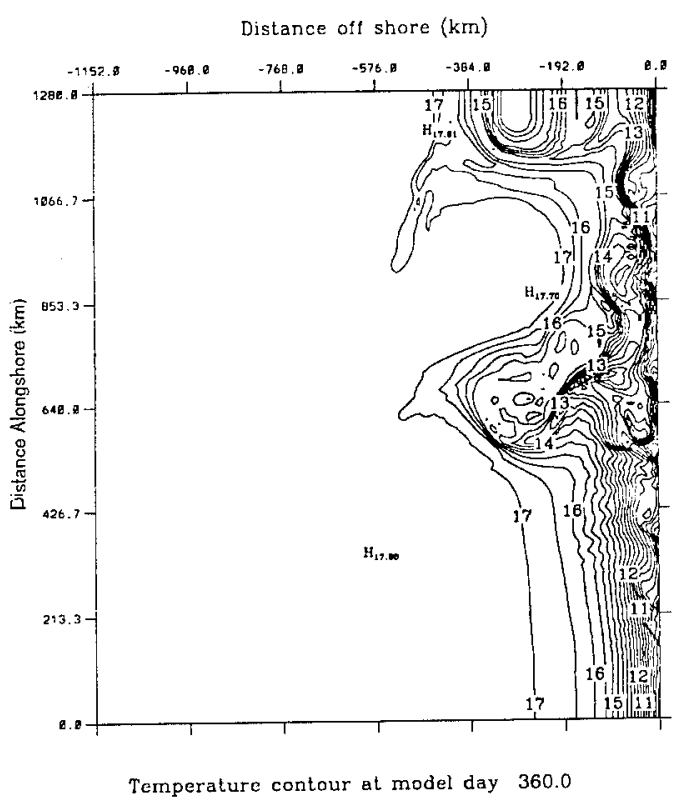

(e) 


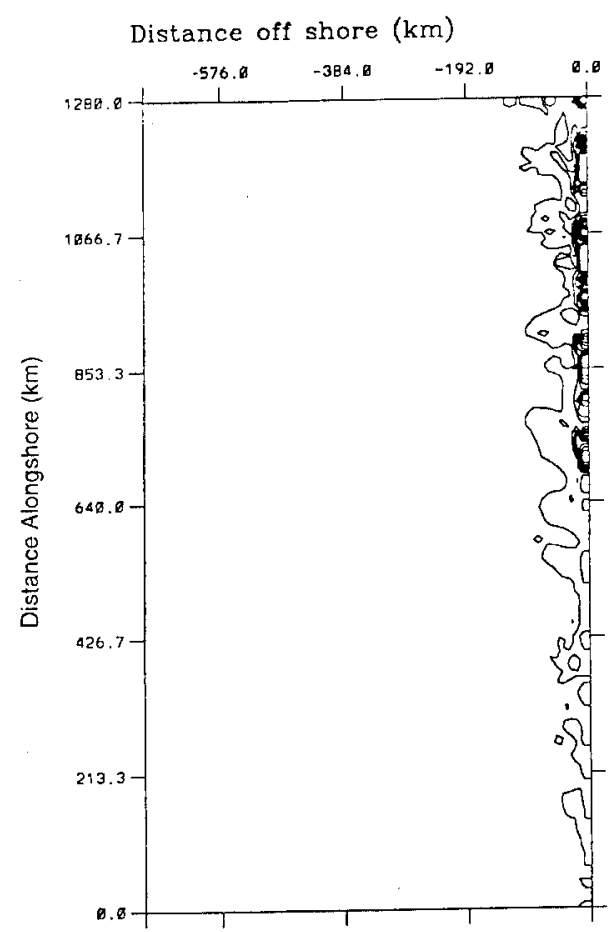

Mean kinetic energy to eddy kinetic energy

(a)

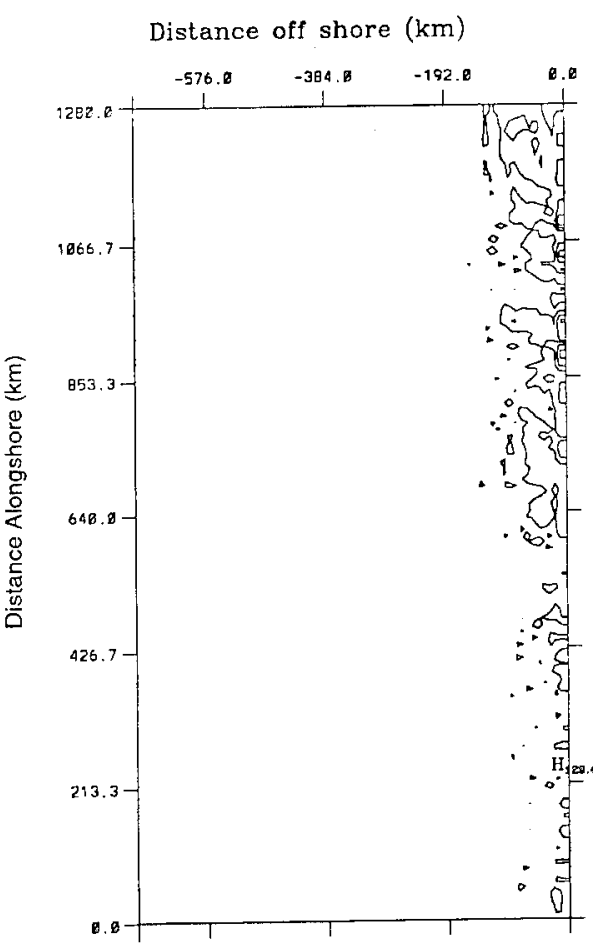

(b)

Figure 13. Experiment 2: Energy transfers in the coastal region of (a) mean to eddy kinetic energy (i.e., barotropic energy transfer) and (b) eddy potential to eddy kinetic energy (i.e., baroclinic energy transfer) for model days 120 to 135 . The contour interval is $10 \mathrm{ergs} \mathrm{cm}^{-3} \mathrm{~s}^{-1}$. 


\begin{tabular}{|c|c|c|c|}
\hline featrres & Obsenation & Expetmes! & Pxporrentz \\
\hline \multicolumn{4}{|c|}{ A Coastal Equatorward Surface Current (coastal Peru-Chile Current (CPC)): } \\
\hline 1 Average Velocity $(\mathrm{cm} / \mathrm{s})$ & $>10(1)$ & $10-30$ & $10-30$ \\
\hline 2 Core Depth $(\mathrm{m})$ & $200(2)$ & 150 & 250 \\
\hline 3 Mass Transport $\left(10^{6} \mathrm{~m}^{3} / \mathrm{s}\right)$ & $19(1)$ & 20 & 20 \\
\hline \multicolumn{4}{|c|}{ B Offshore Equatorward Surface Current (offshore CPC): } \\
\hline 1 Average Velocity $(\mathrm{cm} / \mathrm{s})$ & $10-15(2)$ & not simulated & 10 \\
\hline 2 Core Depth $(\mathrm{m})$ & $<700(2)$ & not simulated & 250 \\
\hline 3 Offshore Distance $(\mathrm{km})$ & $200(2)$ & not simulated & 200 \\
\hline \multicolumn{4}{|c|}{ C Coastal Poleward Undercurrent (Peru-Chile Undercurrent (PCU)): } \\
\hline 1 Average Velocity $(\mathrm{cm} / \mathrm{s})$ & $10(3)$ & $5-15$ & 3-15 \\
\hline 2 Core Depth $(m)$ & $150-200(3)$ & $100-150$ & 150 \\
\hline 3 Offshore Distance $(\mathrm{km})$ & $<200(3)$ & 50 & $75-100$ \\
\hline 4 Mass Transport $\left(10^{6} \mathrm{~m}^{3} / \mathrm{s}\right)$ & $10(3)$ & 10 & 10 \\
\hline D Upwelling & observed & simulated & simulated \\
\hline E Filaments & observed & simulated & simulated \\
\hline F Meanders & observed & simulated & simulated \\
\hline G Eddies & observed & simulated & simulated \\
\hline
\end{tabular}

Table 1. Comparison Of Model Results With Available Observations

References:

(1) Wooster and Reid (1963)

(2) Tchernia (1980)

(3) Fonseca (1989) 


\section{LIST OF REFERENCES}

Arakawa, A. and V. R. Lamb, "Computational Design of the Basic Dynamical Process of the UCLA General Circulation Model," in Methods in Computational Physics, Vol. 17, ed. by J. Chang, Academic Press, New York, p. 173-265, 1977.

Bakun, A., and Nelson, C.S., "The Seasonal Cycle of Windstress Curl in Subtropical Eastern Boundary Current Regions." J. Phys. Oceanogr., 21, 1815-1834. 1991.

Batteen, M.L., and Y.-J. Han, "On the Computational Noise of Finite-Difference Schemes used in Ocean Models." Tellus, 33, 387-396, 1981.

Batteen, M.L., R.L. Haney, T.A. Tielking, and P.G. Renaud, "Numerical Study of Wind Forcing of Eddies and Jets in the California Current System," Mar. Res., 47, 493$523,1989$.

Batteen, M.L., C.N. Lopes da Costa and C.S. Nelson, "A Numerical Study of Wind Stress Curl Effects on Eddies and Filaments off the Northwest Coast of the Iberian Peninsula," J. Mar.Systems. ,3, 294-266, (1992a).

Batteen, M.L., M.J. Rutherford, and E.J. Bayler, "A Numerical Study of Wind- and Thermal-Forcing Effects on the Ocean Circulation off Western Australia," $J$. Phys. Oceanogr., 22, 1406-1433, (1992b).

Camerlengo, A.L., and J.J. O'Brien, "Open Boundary Conditions in Rotating Fluids," $J$. Comput. Physics, 35, 12-35, 1980.

Carton, J.A., "Coastal Circulation Caused by an Isolated Storm," J. Phys. Oceanogr., 14, 114-124, 1994.

Carton, J.A., and S.G.H. Philander, "Coastal Upwelling Viewed as a Stochastic Phenomena,", J. Phys. Oceanogr., 14, 1499-1509, 1984.

Codispoti, L.A., Barber, R.T., and Friederich, G. E., "Do Nitrogen Transformations in the Poleward Undercurrent Off Peru and Chile Have a Globally Significant Influence?" in Poleward Flows Along Eastern Ocean Boundaries, ed. by S.J. Neshyba, C.N.K. Mooers, R.L. Smith and R.T. Barber, Springer-Verlag, New York, p. 281-310, 1989.

Fonseca,T. R., "An Overview of the Poleward Undercurrent and Upwelling Along the Chilean Coast," in Poleward Flows Along Eastern Ocean Boundaries, ed. by S.J.Neshyba, C.N.K.Mooers, R.L. Smith and R.T.Barber, Springer-Verlag, New York, p. 203-218, 1989. 
Gunther,E. R., "A Report on Oceanographical Investigations in the Peru Coastal Current," Discovery Rep.,13,107-276, 1936.

Han, Y.-J., "Numerical Simulation of Mesoscale Eddies," PH.D. Thesis, University of California, Los Angeles, 154 pp., 1975.

Haney, R.L., "A Numerical Study of the Response of an Idealized Ocean to Large-Scale Surface Heat and Momentum Flux," J. Phys. Oceanogr., 4, 145-167, 1974.

Holland, W.R., "The Role of Mesoscale Eddies in the General Circulation of the Ocean Numerical Experiments using a Wind-Driven Quasigeostrophic Model," J. Phys. Oceanogr., 8, 363-392, 1978.

Holland, W.R., and M.L. Batteen, "The Parameterization of Subgrid Scale Heat Diffusion in Eddy-Resolved Ocean Circulation Models," J. Phys. Oceanogr., 16, 200-206, 1986.

Levitus, S., "Climatological Atlas of the World Ocean," NOAA Prof. Paper 13, U.S.Dept.of Commerce, Washington, D.C. 173 pp., 1982.

McCreary, J.P., "A Linear Stratified Ocean Model of the Coastal Undercurrent," Phil. Trans. R. Soc. Lond. A., 302, 385-413, 1981.

McCreary, J.P., Kundu, P.K., Chao, S.Y., "On the Dynamics of the California Current System," J. Mar. Res., 45, 1-32, 1987.

Mooers, C.N.K., and A.R. Robinson, "Turbulent Jets and Eddies in the California Current and Inferred Cross-Shore Transports," Science, 223, 51-53, 1984.

Nelson, C.S., "Wind Stress and Wind Stress Curl over the California Current," NOAA Tech. Rep. NMFS SSFR-714, U.S. Dept. Commerce, 87 pp., 1977.

Pedlosky, J., "Longshore Currents, Upwelling and Bottom Topography," J. Phys. Oceanorgr., 4, 214-226, 1974.

Philander, S.G.H., and Yoon, J.H., "Eastern Boundary Currents and Coastal Upwelling," J. Phys. Oceanogr., 12, 862-879, 1982.

Semtner, A.J., and Y. Mintz, "Numerical Simulation of the Gulf Stream and Midocean Eddies," J. Phys. Oceanogr., 7, 208-230, 1977.

Tchernia, P. "Descriptive Regional Oceanography," Pergamon Press, New York, 253 pp., 1980. 
Trenberth, K.E., W.G. Large, and J.G. Olson, "The Mean Annual Cycle in Global Ocean Wind Stress," J. Phys. Oceanogr., 20, 1742-1760, 1990.

Weatherly, G.L., "A Study of the Bottom Boundary Layer of the Florida Current," $J$. Phys. Oceanogr., 2, 54-72, 1972.

Wooster. W.S.and Gilmartin, M., "The Peru-Chile Undercurrent." J. Mar. Res., 19, 97$122,1961$.

Wooster, W.S., and J.L. Reid, "Eastern Boundary Currents," in The Sea, volume 2, M.N. Hill, ed., Wiley Interscience, New York, pp. 253-280, 1963.

Zeigler, J.M.W.D. Athearn and H. Small, "Profiles across the Peru-Chile Trench," Deep Sea Res. 4, 238-249, 1957. 


\section{INITIAL DISTRIBUTION LIST}

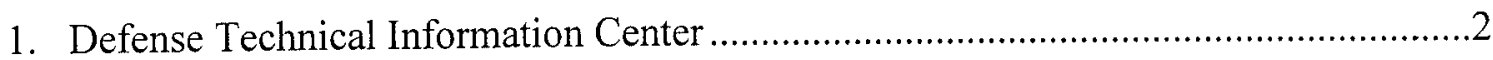
Cameron Station

Alexandria, VA 22304-6145

2. Library, Code 52 2

Naval Postgraduate School

Monterey, CA 93943-5101

3. Chairman (Code OC/Bf).

Department of Oceanography

Naval Postgraduate School

Monterey, CA 93943-5122

4. Chairman (Code MR/Hy)... 1 Department of Meteorology

Naval Postgraduate School

Monterey, CA 93943-5114

5. Dr. Mary L. Batteen, (Code OC/Bv)

Department of Oceanography

Naval Postgraduate School

Monterey, CA 93943-5122

6. LCDR Chih-Ping Hu 2

5F, No. 11, 300 Lane, Fourth Section

Jen-Ai Road, Taipei, Taiwan, 106

7. Dr. T. Kinder .1

Physical Oceanography Devision

Office of Naval Research

800 N. Quincy Street

Arlington, VA 22217 